\title{
Pericellular proteolysis in cancer
}

\author{
Lisa Sevenich and Johanna A. Joyce \\ Cancer Biology and Genetics Program, Memorial Sloan Kettering Cancer Center, New York, New York, 10065, USA
}

Pericellular proteases have long been associated with cancer invasion and metastasis due to their ability to degrade extracellular matrix components. Recent studies demonstrate that proteases also modulate tumor progression and metastasis through highly regulated and complex processes involving cleavage, processing, or shedding of cell adhesion molecules, growth factors, cytokines, and kinases. In this review, we address how cancer cells, together with their surrounding microenvironment, regulate pericellular proteolysis. We dissect the multitude of mechanisms by which pericellular proteases contribute to cancer progression and discuss how this knowledge can be integrated into therapeutic opportunities.

Proteolysis is essential for numerous developmental and physiological processes (Lopez-Otin and Bond 2008). However, deregulation of proteolytic activity underlies many pathological conditions, including cancer (Affara et al. 2009). The first association between proteases and cancer was reported in 1946 when Albert Fischer proposed that the proteolytic activity of cancer cells could be responsible for the degradation of the extracellular matrix (ECM), thereby enhancing invasion of tumor cells into the surrounding tissue (Fischer 1946). Elevated expression of proteases has since been described for multiple cancers and is frequently associated with poor patient prognosis (Duffy 1996). Indeed, PSA (prostate-specific antigen), which has been one of the most frequently used biomarkers in cancer, is a serine protease (Lilja et al. 2008). There are $>550$ known human proteases, representing the second most abundant class of enzymes after ubiquitin ligases. Mammalian proteases are classified into five distinct enzymatic classes based on their catalytic mechanism: aspartic, cysteine, metallo, serine, and threonine (Lopez-Otin and Bond 2008). Given the essential requirement to tightly regulate proteolytic activity (Puente et al. 2003), there are specific endogenous protease inhibitors for each class, comprising $\sim 150$ proteins in total. These include tissue inhibitors of metalloproteinases (TIMPs), cystatins, and serpins that inhibit matrix metalloproteinases (MMPs), cysteine, and serine proteases, respectively (Rawlings et al. 2014).

Pericellular proteases form a particularly important category within the cancer degradome, as the majority

[Keywords: invasion; macrophages; metastasis; migration; proteases; tumor microenvironment]

Corresponding author: johanna@joycelab.org

Article is online at http://www.genesdev.org/cgi/doi/10.1101/gad.250647.114. of known substrates that are cleaved or processed during neoplastic progression are localized in the extracellular space. The complexity of pericellular proteolysis in cancer arises from the structural and functional diversity of proteases and their interacting partners, which synergize to establish an environment that allows tumor cells to thrive, invade into surrounding tissue, and colonize distant organs. In particular, the role of matrix-degrading proteases, such as MMPs, has been extensively studied over the past several decades because of their potent ability to degrade ECM components, which can lead to increased tumor cell invasion and metastasis (Kessenbrock et al. 2010). However, a growing body of literature has identified diverse mechanisms by which proteases from all catalytic classes positively or negatively affect cancer progression and metastasis through complex and highly regulated processes that involve cleavage of cell adhesion molecules, growth factors, cytokines, or kinases (Mohamed and Sloane 2006; Murphy 2008; Kessenbrock et al. 2010; Lopez-Otin and Hunter 2010; Tang and Han 2013).

In order to understand the complexity of pericellular proteolysis, we must also appreciate that proteases are organized in proteolytic webs or networks (auf dem Keller et al. 2007; Mason and Joyce 2011) and rarely act as individual players or in unidirectional cascades. Proteases are synthesized as inactive zymogens, and the majority of proteases require activation through other proteases, which leads to amplification loops as the number of targets increases at each successive step. Protease activity is controlled in part by the presence of endogenous inhibitors for each catalytic class, as discussed above. To systematically study interactions of proteases and their inhibitors within the protease web, Overall and colleagues (Fortelny et al. 2014) recently mathematically modeled the interactions of $>1200$ proteins and showed connections between $>140,000$ pairs of proteases, substrates, and inhibitors. This remarkable degree of "interconnectedness" emphasizes the importance of recognizing and analyzing the multitude of regulatory interactions in order to fully understand the functions of proteases and their interacting partners in complex in vivo environments.

(C) 2014 Sevenich and Joyce This article is distributed exclusively by Cold Spring Harbor Laboratory Press for the first six months after the full-issue publication date (see http://genesdev.cshlp.org/site/misc/terms.xhtml). After six months, it is available under a Creative Commons License (Attribution-NonCommercial 4.0 International), as described at http:// creativecommons.org/licenses/by-nc/4.0/. 


\section{Pericellular proteases}

Pericellular proteases can be classified into two broad categories based on their localization within the extracellular space: (1) membrane-associated proteases and (2) secreted proteases (Fig. 1). Prototypic pericellular proteases are membrane-type proteases that are covalently attached to the plasma membrane, thereby confining proteolytic activity to the pericellular space. Based on the type of plasma membrane attachment, membranetype proteases are subdivided into type 1 transmembrane proteases (C-terminal transmembrane domain; e.g., ADAMs and MT1-MMP/MMP14), type 2 transmembrane proteases (N-terminal transmembrane domain; e.g., MMP23 and MT-SP1), and glycosylphosphatidylinositol (GPI)-anchored proteases (e.g., MMP17, MMP25, and PRSS21) (Friedrich et al. 2002; Seals and Courtneidge 2003; Nagase et al. 2006; Antalis et al. 2011). In addition, alternative protein trafficking routes can lead to exocytosis of typically endosomal/lysosomal proteases such as cathepsins through either the secretory pathway or fusion of lysosomes with the extracellular membrane (Brix et al. 2008). Secreted proteases can be tethered to the plasma membrane by binding to receptors such as urokinase plasminogen activator receptor (UPAR) (Blasi and Sidenius 2010) or through association with interacting partners such as integrins (Hood and Cheresh 2002), annexin II (Bharadwaj et al. 2013), and the cell surface glycoprotein CD44 (Marrero-Diaz et al. 2009). Moreover, proteases can interact with cell surface-associated heparan sulfate proteoglycans (HSPGs) (Sarrazin et al. 2011), collagens, and fibrin (Makowski and Ramsby 1998; Olson et al. 1998; Rosenblum et al. 2010) in the extracellular space, resulting in enhanced enzyme stability.

\section{Induction and regulation of pericellular proteolysis in cancer}

Unlike other post-translational modifications, proteolysis is a terminal and irreversible process. As such, tight regulation of protease activity is essential for confining its action to the requisite locations and conditions, thereby protecting the cell from extensive, uncontrolled proteolysis. Protease expression and activity are thus subject to high cell type and context specificity, which involves multiple regulatory mechanisms, including subcellular compartmentalization, inhibition by endogenous inhibi-
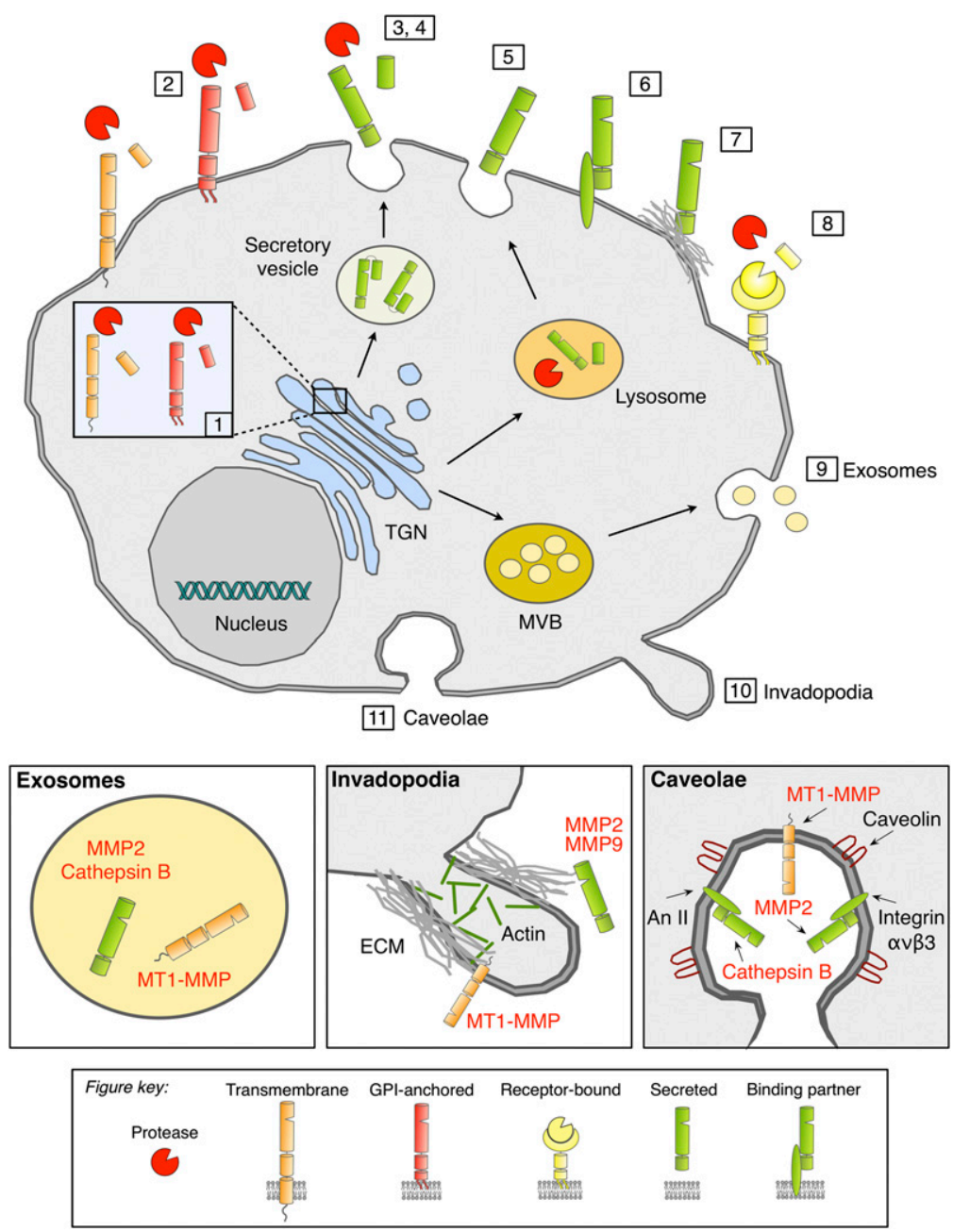

Figure 1. Protein trafficking of pericellular proteases. Pericellular proteases are synthesized in the endoplasmic reticulum (ER) and transported through the Golgi complex to the trans-Golgi-network (TGN). (1) Membrane-associated proteases are activated by furin in the TGN and reach the cell surface as active proteases. (2) Alternatively, membrane-associated proteases can be transported to the cell surface as inactive precursor proteins and are proteolytically activated in the pericellular space. (3) Classically secreted proteases are transported to the plasma membrane (PM) through the constitutive secretory pathway and are proteolytically activated in the pericellular space following secretion. Proteases that are typically localized to endosomes or lysosomes can be transported to the extracellular space through alternative trafficking via the secretory pathway (4) or through lysosomal exocytosis (5). Lysosomal proteases that reach the extracellular space via the secretory pathway are secreted as proenzymes and require proteolytic activation, while proteases that trafficked through the lysosome are activated within the lysosome and secreted as active enzymes. Secreted proteases can be tethered to the PM through interacting partners such as CD44, integrins, or annexin II (An II) (6) or through binding to ECM components (7). (8) Some secreted proteases are bound to specific receptors; e.g., uPA binds to uPAR. (9) Proteases can also be released through exosomes that originate from multivesicular bodies (MVBs), which leads to secretion into the extracellular space or transfer to adjacent cells. Accumulation or localized release of pericellular proteases is associated with PM microdomains such as invadopodia (actinrich protrusions) (10) or caveolae (a subset of lipid rafts) (11), which are represented at higher magnification in the bottom panels. 
tors, and the requirement for zymogen activation (Piperi and Papavassiliou 2012). During neoplastic progression, however, these regulatory checkpoints are frequently overridden through a number of different mechanisms (Rakashanda et al. 2012). Protease gene expression can be induced in cancer cells and tumor-associated stromal cells through cell-intrinsic and cell-extrinsic stimuli by mechanisms ranging from genetic alterations to posttranslational modifications. The majority of the described transcriptional or post-translational alterations of protease expression in cancer have downstream effects on the efficiency of protein synthesis, leading to aberrant levels of proteases that are transported to the cell surface and/or secreted, which consequently impacts the extent of pericellular proteolysis. However, there are also a few examples reported to date in which genetic alterations have a direct effect on protein trafficking of proteases. Among 13 different $A D A M$ genes that encode catalytically active proteases (Edwards et al. 2008), ADAM12 is the most frequently somatically mutated $A D A M$ gene in human breast cancers according to the Catalogue of Somatic Mutations in Cancer (COSMIC) database, harboring six confirmed somatic mutations (Sjoblom et al. 2006). Interestingly, two mutations described for ADAM12 in breast cancer resulted in altered intracellular protein trafficking and loss of ADAM12 at the cell surface in human and mouse breast cancer (Dyczynska et al. 2008; Qi et al. 2014).

Numerous studies have identified various proteases showing higher gene expression in response to increased oncogene activity, thus providing insight into the signaling pathways engaged in oncogene-induced protease expression. For example, overexpression of the ErbB2 oncogene can lead to increased expression of MMPs and uPA in ErbB2-driven breast cancer models (Yong et al. 2010). Rafn et al. (2012) identified the key components of an ErbB2-activated signaling network in which expression of cathepsin $B$ and cathepsin $L$ is induced by the myeloid zinc finger-1 (MZF-1) transcription factor. Interestingly, oncogenic Ras has been shown to induce alterations in the trafficking of cathepsin B, leading to an increase in membrane-associated cathepsin B (Sloane et al. 1994; Cavallo-Medved et al. 2003) and indicating that multiple oncogenic pathways can impact protease levels and trafficking. Several recent reports have described roles for microRNAs (miRNAs) in post-transcriptional protease gene regulation. Potential miRNA-binding sites have been predicted in the $3^{\prime}$ untranslated region of $A D A M 17, u P A$, and several MMPs (Dalmay and Edwards 2006; Bracken et al. 2014), and a growing number of studies have provided functional validation of miRNAmediated regulation of proteases in cancer (Li and Li 2013). It has also been reported that miRNAs contribute to the down-regulation of inhibitors and other protease regulators, which in turn leads to protease activation (Gabriely et al. 2008; Reis et al. 2012). In future studies, it will be critical to determine whether the other reported mechanisms that alter protease expression in cancer similarly change protein localization and consequently impact pericellular proteolysis.

\section{Regulation of protease trafficking and pericellular proteolysis}

Localization of proteases in the pericellular space
and interactions with binding partners

As described earlier, membrane-type proteases are covalently attached to the plasma membrane to confine proteolytic activity to the pericellular space. Secreted proteases can also be tethered to the plasma membrane through their interaction with distinct binding partners (Fig. 1). For example, uPAR is a GPI-anchored protein that binds and activates the serine protease uPA (Huai et al. 2006), thus regulating its proteolytic activity at the cell surface (Blasi and Sidenius 2010). Secreted MMPs (e.g., MMP2 and MMP9| can localize to the plasma membrane by binding to $\alpha \nu \beta 3$ and $\alpha 4 \beta 1$ integrin or CD44 (Brooks et al. 1996; Yu and Stamenkovic 1999; Redondo-Munoz et al. 2008). Cathepsin X/Z, which contains an Arg-Gly-Asp (RGD) motif in its propeptide, was shown to bind to RGDrecognizing integrins such as $\alpha \nu \beta 3$ (Lechner et al. 2006). It has been demonstrated that stromal cell-derived proteases can be transferred onto the surface of tumor cells through interactions with $\alpha \nu \beta 3$ integrins and CD44, thus enhancing the invasive potential of tumor cells (Brooks et al. 1996; Yu and Stamenkovic 1999; Akkari et al. 2014). Sloane and colleagues (Cavallo-Medved and Sloane 2003; CavalloMedved et al. 2009) proposed that the localization of proteases in caveolae is important for their ability to degrade ECM components. Cathepsin B can be localized in caveolae through the association with annexin II heterotetramers (Fig. 1; Cavallo-Medved et al. 2005), and, interestingly, annexin II is also involved in the biosynthesis of multivesicular endosomes, in which procathepsin $\mathrm{L}$ is stored in association with the tetraspanin CD63 (Collette et al. 2004).

Direct binding of pericellular proteases to ECM components represents another mechanism to achieve enzymesubstrate proximity in the pericellular space (Fig. 1). Pro-MMP9 shows high affinity to the $\alpha 2(\mathrm{IV})$ chain of collagen IV and fibrin (Makowski and Ramsby 1998; Olson et al. 1998). During fibrinolysis, latent fibrin-bound MMP9 is processed to lower-molecular-weight forms consistent with proteolytic activation of MMP9 (Olson et al. 1998). Interactions of matrix-degrading proteases with glycosaminoglycans such as heparan, heparan sulfate, or keratin are critical for enzyme activity and autolytic activation (Ra et al. 2009) and the stabilization of enzyme structure even at alkaline $\mathrm{pH}$ (Almeida et al. 1999).

Enzymatic stabilization is particularly important for pericellular proteases that reach the extracellular space via alternative trafficking routes; e.g., lysosomal cathepsins (Almeida et al. 2001). Given that cathepsins have optimal activity at the acidic $\mathrm{pH}$ of the lysosome, the development of an acidic pericellular environment is likely to be critical for their tumor-promoting functions outside of the cell. Indeed, several in vivo studies that have measured extracellular $\mathrm{pH}$ levels in tumors have found it to be substantially lower than normal tissue (Gerweck and Seetharaman 1996; Gallagher et al. 2008). Extracellular acidification is regulated in part by the $\mathrm{Na}^{+} / \mathrm{H}^{+}$exchanger (NHE1). Interestingly, NHE1 interaction with CD44 can induce 
cathepsin B activation and lead to increased breast cancer invasion (Bourguignon et al. 2004). Moreover, an acidic pericellular $\mathrm{pH}$ induces the redistribution of cathepsin Bcontaining vesicles toward the cell surface and leads to increased secretion of cathepsin B, resulting in enhanced pericellular proteolysis (Rozhin et al. 1994; Rothberg et al. 2013).

\section{Invadopodia and podosomes can serve as local storage depots of proteases at the cell surface}

Another means by which proteases can accumulate and be released locally in the pericellular environment is via specialized actin-rich protrusions of the plasma membrane, termed podosomes in normal cells (including macrophages and dendritic cells) or invadopodia in cancer cells (Fig. 1; Murphy and Courtneidge 2011). These protrusions facilitate adhesion of cells to the ECM and also act as a concentrated source of proteases, thus coupling cell adhesion with proteolysis-dependent cell migration, which is critical for coordinated invasion. The proteases localized in invadopodia include MT1-MMP, MMP2, MMP9, ADAM12, ADAM15, ADAM19, cathepsins, and seprase (Murphy and Courtneidge 2011), which are secreted to contribute to localized pericellular proteolysis.

A central question in the biology of invadopodia is how proteolytic activity is precisely localized at discrete plasma membrane sites to produce focal ECM degradation. The mechanisms underlying protease localization to invadopodia and subsequent secretion have been best defined for MT1-MMP. Recruitment of cortactin to future sites of matrix degradation appears to act as the cue for subsequent MT1-MMP trafficking to these locations (Artym et al. 2006). MT1-MMP can be delivered to invadopodia through multiple pathways, including endocytic recycling, microtubule-mediated trafficking, and mobilization of intracellular stores (Murphy and Courtneidge 2011). The scaffold proteins Tks4 and Tks5 then cooperate to regulate subsequent steps: Tks5 promotes invadopodium formation (Seals et al. 2005), and Tks4 then appears to stabilize MT1MMP in the invadopodium, enabling localized activation of MMPs followed by matrix degradation (Buschman et al. 2009). Inhibition of invadopodia components, including Tks5, reduced proteolytic activity and lung adenocarcinoma metastasis (Li et al. 2013) and experimental breast-to-lung metastasis (Leong et al. 2014) in animal models.

Cholesterol- and sphingolipid-enriched plasma membrane microdomains, so-called lipid rafts (Lingwood and Simons 2010), are another important component of invadopodia, which regulate the polarized delivery of proteases and other regulatory proteins to sites of localized degradation. Caveolin-1 is a ubiquitously expressed scaffolding protein that is enriched in caveolae, a subtype of lipid rafts (Parton and Simons 2007). Besides its critical role in cholesterol transport to the plasma membrane during the formation of invadopodia, caveolin-1 has also been shown to cotraffic and colocalize with MT1-MMP in invadopodia (Fig. 1; Yamaguchi et al. 2009). Interestingly, invadopodia also contain $\mathrm{pH}$ regulators, including the V-ATPases and NHE1 discussed above, which help regulate protease activation and stability in the acidic pericellular environment (Brisson et al. 2012; Gould and Courtneidge 2014).

\section{Exosomes as a means to regulate and transfer proteases between cells}

Exosomes are small membrane vesicles (30-100 nm) that originate from multivesicular bodies inside cells and are subsequently released by fusion with the plasma membrane (Fig. 1). Exosomes contain a variety of RNA species (mRNAs and miRNAs), proteins (growth factors, cytokines, RAB family members, etc.), proteases, and protease inhibitors (McCready et al. 2010; Peinado et al. 2012). Exosomes have emerged in recent years as an important mechanism for delivering cargo between cells, thus contributing to cellular interactions within the tumor microenvironment (Peinado et al. 2011). There are a number of different mechanisms by which exosomes have been shown to modulate pericellular proteolysis and thereby enhance cell invasion. One example is via heat shock protein-90 $\alpha$ (HSP90 $\alpha$ ) secretion from exosomes, which then binds to client proteins, including tissue plasminogen activator (tPA) and annexin II, resulting in activation of the proteases plasmin and MMP2 (Eustace et al. 2004; McCready et al. 2010). MT1-MMP is similarly secreted from exosomes into the extracellular space, where it activates pro-MMP2 and degrades type I collagen and gelatin (Hakulinen et al. 2008). The contents of exosomes can also increase protease expression, thus impacting pericellular proteolysis indirectly. For example, exosomes isolated from activated $\mathrm{T}$ cells were shown to promote melanoma and lung cancer invasion by increasing the expression of $M M P 9$ via Fas signaling (Cai et al. 2012). Khokha and colleagues (Shimoda et al. 2014) recently demonstrated that fibroblasts engineered to be deficient for all four Timp genes functionally recapitulate cancer-associated fibroblasts (CAFs) and activate oncogenic signaling in cancer cells through ADAM10-rich exosomes, which lead to increased cancer cell motility. Finally, proteolysis has also been shown to occur within exosomes in the case of ADAM10, which rapidly cleaves the immunoglobulin $\mathrm{E}$ ( $\mathrm{IgE}$ ) receptor $\mathrm{CD} 23$ prior to its release from B cells (Mathews et al. 2010).

\section{Pericellular proteolysis in the tumor microenvironment}

It is now well established that complex interactions between cancer cells and stromal cells within the tumor microenvironment play important roles in cancer progression at both the primary and metastatic sites (Quail and Joyce 2013). Pericellular proteolysis is increasingly recognized as a key process in creating a cancer-permissive extracellular milieu (Fig. 2). Paracrine signaling between cancer cells and stromal cells as well as stimuli from noncellular components have been shown to induce expression and secretion of proteases in cancer cells and various stromal cell types. The proinflammatory cytokines tumor necrosis factor- $\alpha$ (TNF- $\alpha$ ) and transforming growth factor- $\beta$ (TGF- $\beta$ ) play central roles in this process. Breast cancer cells induce uPA and MMP9 expression in 


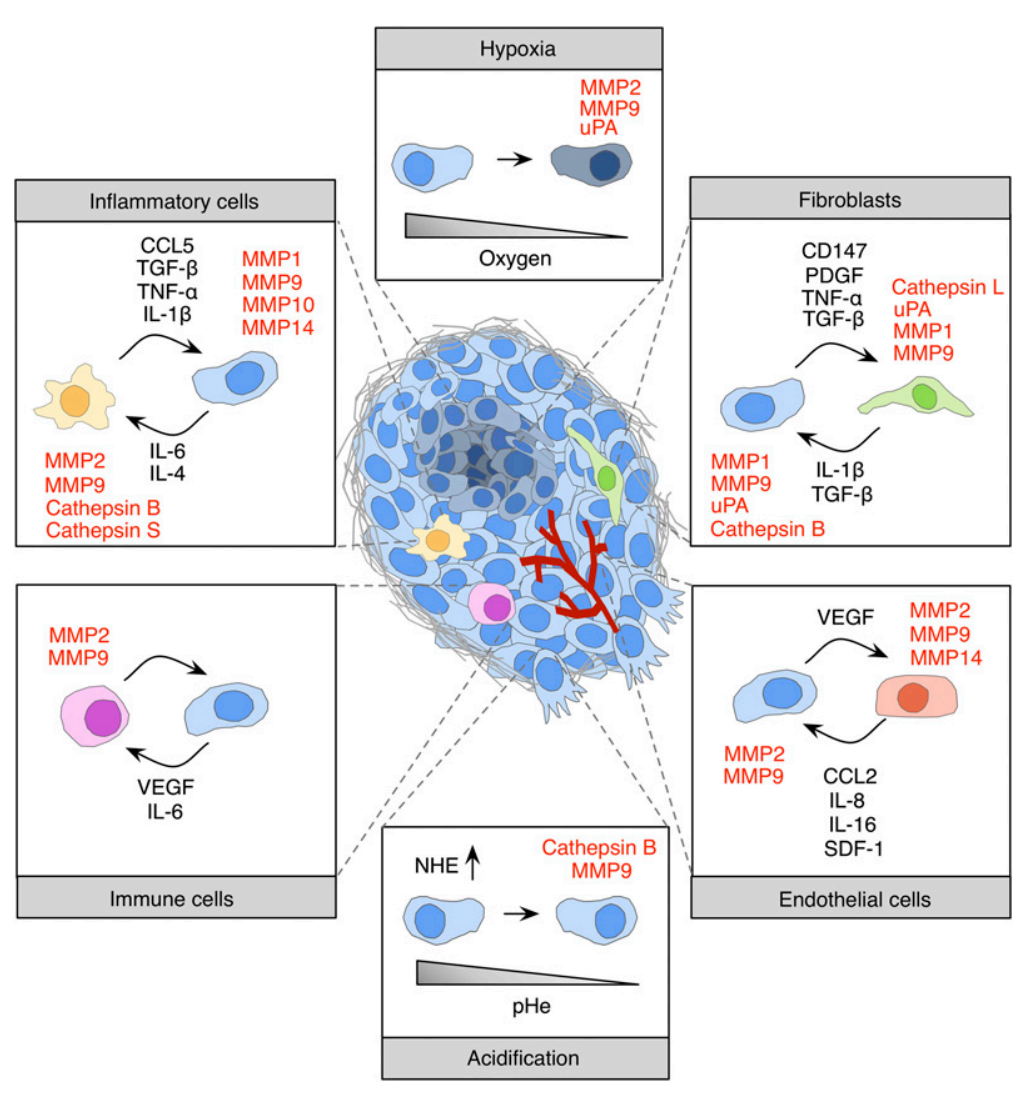

Figure 2. Microenvironmental regulation of pericellular proteolysis. Interactions between tumor cells and noncancerous stromal cells, including fibroblasts, inflammatory cells (e.g., macrophages, neutrophils, and dendritic cells), immune cells (e.g., $B$ and $T$ cells), and endothelial cells, have been reported to induce protease expression and activity within the tumor microenvironment. Paracrine signaling between tumor cells and stromal cells is orchestrated through cytokines and growth factors. Noncellular stimuli such as hypoxia or acidic extracellular $\mathrm{pH}$ are also known inducers of protease expression and activity. stromal fibroblasts via secretion of TGF- $\beta$ and/or TNF- $\alpha$ (Sieuwerts et al. 1998; Stuelten et al. 2005). Recent reports propose a shift from TGF- $\beta$ signaling in primarily epithelial cells in normal and adenoma tissue to stromal cells (i.e., fibroblasts, T cells, macrophages, and endothelial cells), which promoted tumor invasion and metastasis (Calon et al. 2012; Hawinkels et al. 2014). Other tumor cell-derived growth factors, such as basic fibroblast growth factor (bFGF), platelet-derived growth factor (PDGF), and epidermal growth factor (EGF), have been shown to induce $M M P 1$ and $u P A$ expression in fibroblasts (Kaminski et al. 2006; Noskova et al. 2009).

Another important regulator of MMP expression is the ECM metalloproteinase inducer (EMMPRIN/CD147). CD147 is a highly glycosylated Ig-like receptor that is expressed on the surface of various tumor cell types (Gabison et al. 2005) and nonmalignant cells, including macrophages (Major et al. 2002). Homotypic interactions between glycosylated IgII domains of CD147 on tumor cells and fibroblasts are known to increase expression of MMP1, MMP2, MMP3, and MT1-MMP in fibroblasts (Sameshima et al. 2000; Sun and Hemler 2001; Papadimitropoulou and Mamalaki 2013). The induction of $M M P$ expression in fibroblasts in response to CD147 stimulation was shown to be dependent on downstream MAPK p38 signaling (Lim et al. 1998). In addition to homotypic interactions between CD147 molecules on tumor cells and fibroblasts, it was proposed that up-regulation of CD147 in noninvasive breast cancer cells is sufficient to induce an invasive phenotype associated with high MT1-MMP activity in invadopodia (Grass et al.
2012) as a result of enhanced EGFR-Ras-ERK signaling that is initiated through a signaling complex between CD147 and CD44 (Grass et al. 2013).

Infiltrating inflammatory cells-such as tumor-associated macrophages (TAMs), dendritic cells, mast cells, and immune cells (e.g., B and T cells)_are also critical cellular constituents of the tumor microenvironment and an important source of proteases during tumorigenesis. Interleukin-6 (IL-6) is one of the major inflammatory cytokines that has been linked to cancer progression and is secreted by different cell types, including fibroblasts, endothelial cells, keratinocytes, macrophages, lymphocytes, and various cancer cell types (Guo et al. 2012). IL-6 induces cathepsin B, MMP2, and MMP9 expression and secretion from breast tumor-associated monocytes (Mohamed et al. 2010) as well as MMP9 expression in macrophages (Kothari et al. 2014). It was also demonstrated that keratinocyte-derived IL-6 activates fibroblasts and promotes invasive tumor growth in squamous cell carcinoma via enhanced expression and activation of MMP2 (Depner et al. 2014). Another important cytokine that is typically secreted by $\mathrm{T}$ helper (Th) type 2 (Th2) cells is IL-4. Increased levels of IL-4 expression in tumor cells have been reported for several human cancers, including breast, colon, lung, and pancreatic cancer (Prokopchuk et al. 2005; Todaro et al. 2008). Interestingly, tumor cell-derived IL-4 induces cathepsin B and cathepsin S expression in TAMs, resulting in enhanced growth and invasion of pancreatic neuroendocrine tumors (Gocheva et al. 2010). TAMs in turn produce high levels of proinflammatory cytokines, including IL-1 $\beta$, TNF- 
$\alpha$, TGF- $\beta$, and chemokines such as CCL5. TAM-derived IL-1 $\beta$ induces expression of MMP1, MMP10, and MMP14 in metastatic renal cell carcinoma (Petrella and Vincenti 2012), and macrophage-derived CCL5 has been shown to induce MMP9 expression, which promotes pancreatitisinduced acinar-to-ductal metaplasia (Liou et al. 2013).

It is well established that cancer cells secrete angiogenic factors to recruit endothelial cells. However, relatively little is known about the effects of endothelial cells on tumor cell behavior in relation to proteolysis. Recent publications demonstrate that endothelial cells secrete different cytokines, including CCL2, IL-8, and IL-16, which induce expression of MMP2 and MMP9 in hepatocellular carcinoma (Wang et al. 2013). Endothelial cell-derived stromal-derived factor-1 (SDF-1/CXCL12) has been shown to induce cathepsin $B$ and MMP9 expression in U87 glioma cells, which leads to increased cancer cell invasion and enhanced endothelial cell proliferation, suggesting a paracrine mechanism in regulating glioma angiogenesis (Kenig et al. 2010). Collectively, these different examples demonstrate how heterotypic signaling loops between distinct cell types in the tumor microenvironment can have potent amplifying effects, resulting in increased pericellular proteolysis, which is necessary for multiple tumorigenic processes, as discussed in the following section.

\section{Tumor-promoting and tumor-suppressive functions of pericellular proteases}

\section{Invasion and metastasis}

Pericellular proteases have been shown to exert both tumor-promoting and tumor-suppressive functions (Fig. 3).
A

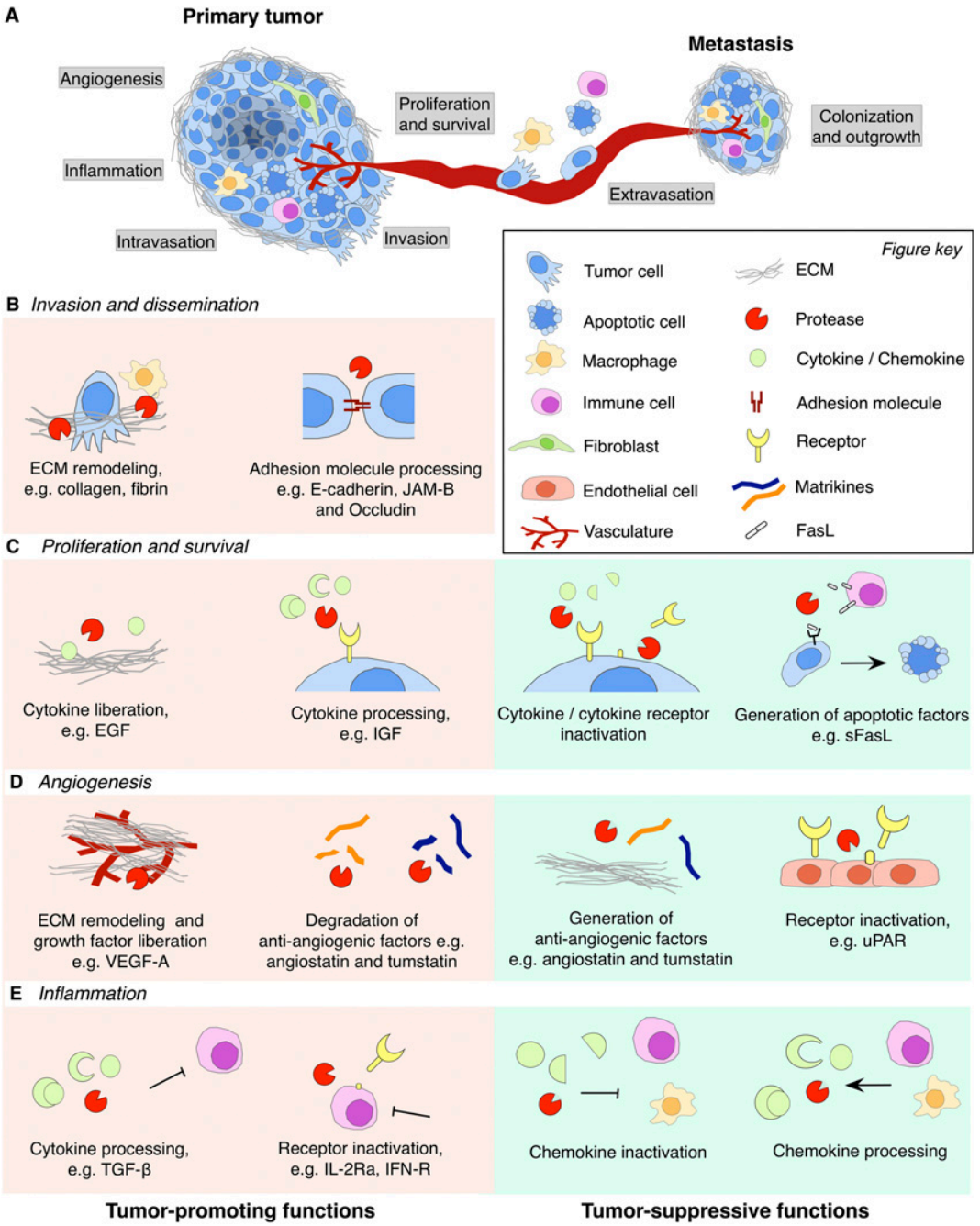

Figure 3. Tumor-promoting and tumor-suppressive functions of pericellular proteases in cancer. (A) Schematic overview of rate-limiting steps during primary tumor growth and metastasis that are regulated by pericellular proteases. (B) Cleavage of different substrates modulates distinct processes in primary cancer progression and metastatic dissemination. Pericellular proteases promote local invasion of tumor cells, intravasation into the circulation, and extravasation at the secondary site by cleavage of ECM components and cell adhesion molecules such as E-cadherin, JAM-B, or occludin. (C) Pericellular proteases promote tumor cell proliferation and survival by ECM processing, which liberates cytokines that are tethered to the ECM. Certain cytokines require proteolytic cleavage for their activation or bioavailability; e.g., cleavage of IGF-BP liberates IGF. Conversely, proteases can reduce tumor cell proliferation and survival by proteolytic degradation of cytokines or inactivation of cytokine receptors by ectodomain shedding. Generation of apoptotic factors (e.g., sFasL) induces apoptosis in tumor cells. $(D)$ Pericellular proteases exert proangiogenic functions by ECM remodeling during vessel sprouting and degradation of anti-angiogenic factors such as angiostatin and tumstatin. However, more restricted proteolytic processing of ECM components can lead to the generation of these same anti-angiogenic matrikines, angiostatin and tumstatin. Thus, the balance between these activities will determine whether pericellular proteolysis is proangiogenic or anti-angiogenic. Cleavage of UPAR on the cell surface of endothelial cells also inhibits angiogenesis by limiting endothelial cell invasion. $(E)$ Pericellular proteases regulate the activation status of different stromal cell types and orchestrate the recruitment of

tumor-promoting or tumor-suppressing inflammatory cells. Proteolytic liberation of TGF- $\beta$ leads to suppression of T-cell responses against tumor cells, and shedding of IL-2R $\alpha$ or IFN-R leads to alterations in the activation status of T cells. Pericellular proteases are also implicated in anti-cancer immune responses, e.g., by inactivating members of the CC and CXC chemokine family, thereby blocking the recruitment of tumor-promoting inflammatory cells. Conversely, processing of chemokines may also recruit tumorsuppressive inflammatory cells. 
Moreover, the same protease can have opposing roles depending on the organ site (Gocheva et al. 2006; Vasiljeva et al. 2006; Dennemarker et al. 2010; Ruffell et al. 2013), which is suggestive of critical influences of the cell of origin, tissue microenvironment, and likely additional factors in determining the functional outcome of proteases in cancer. A multitude of pericellular proteases have been identified and characterized that can essentially cleave all ECM components, including collagens, noncollagenous glycoproteins (e.g., laminin and fibronectin), and proteoglycans (e.g., perlecan, decorin, or CD44). Time-lapse imaging was instrumental in demonstrating that multistep pericellular proteolysis is important in the transition from individual cell migration (involving the generation of tube-like matrix defects) to a uniform and widespread clearance of ECM in the context of collective cancer cell invasion (Wolf et al. 2007). Besides ECM turnover, proteases also contribute to the disruption of physical barriers by the cleavage of cell adhesion molecules and intercellular junction proteins. E-cadherin, the main component of adherens junctions, is cleaved by the cysteine cathepsins B, L, and S (Gocheva et al. 2006) as well as metalloproteinases such as MMP3 and MMP7 (Noe et al. 2001) or ADAM10, ADAM15 (Najy et al. 2008; Grabowska et al. 2012), and meprin- $\beta$ (Huguenin et al. 2008). Proteolytic cleavage of E-cadherin abrogates cell-cell adhesion of epithelial cells, thus promoting cancer cell invasion and metastasis. In addition to weakening intercellular adhesion, there is accumulating evidence that soluble E-cadherin fragments exert important biological functions, for example, by modulating MAPK and PI3K/Akt/mTOR signaling (Brouxhon et al. 2014) as well as ErbB receptor activation (Najy et al. 2008). Targeting of E-cadherin by MMP3 and MMP7 generates bioactive fragments that promote invasion and induce an epithelial-to-mesenchymal transition (EMT) in mammary epithelial cells (Lochter et al. 1997; Noe et al. 2001).

In addition to primary tumor invasion, pericellular proteases also have highly specialized roles in tumor cell intravasation into the circulation and extravasation at secondary sites (Fig. 3A,B). These steps of the invasionmetastasis cascade require that tumor cells breach tissuespecific vascular barriers, which may display differential permeability based on cellular composition and the expression of adhesion molecules. Disruption of vascular barriers by pericellular proteases is mediated through different mechanisms, including the detachment of mural cells, processing of receptors, and cleavage of adhesion molecules. For example, MMP17 facilitates breast cancer cell intravasation by promoting the detachment of pericytes from blood vessels, which also causes increased tumor vascular leakage (Chabottaux et al. 2009). Tumor cellderived MMP1 cleaves and activates protease-activated receptor-1 (PAR-1) on endothelial cells, which leads to increased endothelial permeability and trans-endothelial migration of cancer cells (Juncker-Jensen et al. 2013). MMP1 and MMP2 are also critical mediators of breast cancer cell extravasation through lung capillaries to seed lung metastases (Minn et al. 2005; Gupta et al. 2007). Metastasis to bone, another common site for breast cancer, is characterized by osteolytic bone destruction, which is regulated at least in part by ADAMTS1 and MMP1 via the release of membrane-bound EGF ligands, heparin-binding EGF (HB-EGF), TGF- $\alpha$, and amphiregulin. This results in suppression of osteoprotegerin expression in osteoblasts and the subsequent promotion of osteoclast differentiation, which then mediate osteolysis (Lu et al. 2009). Likewise, osteoclast-derived MMP7 can process receptor activator of nuclear factor-кB ligand (RANKL) at the tumor-bone interface, which gives rise to a soluble form that promotes osteoclast activation. Consequently, prostate cancer-induced osteolysis is significantly reduced in MMP7-deficient mice (Lynch et al. 2005). Prostate cancer metastasizes to several organ sites, including bone, lymph nodes, lungs, and the liver (Bubendorf et al. 2000), and EMT has been shown to be important for dissemination in several studies. For example, the transmembrane protease Ser2 (TMPRSS2) can cleave prohepatocyte growth factor (pro-HGF), and activated HGF promotes c-Met receptor signaling to initiate a proinvasive EMT phenotype. Interestingly, although primary prostate cancer growth was actually accelerated in TMPRSS2-deficient mice, metastasis to the liver was significantly reduced (Lucas et al. 2014).

The blood-brain barrier (BBB) - composed of endothelial cells, astrocytes, and pericytes-presents one of the most formidable structures for cancer cells to penetrate. Cathepsin $\mathrm{S}$ was recently shown to cleave the junctional adhesion molecule-B (JAM-B), a tight junction protein that is highly enriched in brain endothelial cells. Shedding of JAM-B leads to disruption of BBB integrity and thus facilitates breaching of the BBB by breast cancer cells. Consistently, genetic or pharmacological inhibition of cathepsin S significantly impaired the development of experimental breast-to-brain metastasis (Sevenich et al. 2014). Similarly, degradation of the tight junction proteins claudin-5 and occludin by MMP2 and MMP9 secreted by leukemic cells led to BBB breakdown and contributed to CNS involvement in acute leukemia (Feng et al. 2011). As these representative examples indicate, proteases can promote invasion and metastasis to multiple organ sites through a plethora of different molecular mechanisms. Notably, levels of protease expression correlate with organ-specific metastasis in patients (Lu et al. 2009; Sevenich et al. 2014), revealing both potential prognostic markers and therapeutic targets.

\section{Proliferation and survival}

Not only is matrix degradation required for the breakdown of ECM components to enhance tumor cell invasion and metastasis, it is also a critical mediator of cell proliferation and survival by regulating the bioavailability of growth factors through different mechanisms, including the liberation or activation of growth factors (Fig. 3C). Many growth factors are secreted as part of a latent complex in order to prolong their half-life. However, association with binding proteins limits their bioavailability (Baxter 2014). Proteolytic processing of binding proteins is therefore necessary to release proteases to allow interactions with their cognate receptors 
to induce proliferation or inhibit apoptosis. For example, insulin-like growth factors (IGFs) are released when IGFbinding proteins (IGFBPs) are cleaved by MMPs (e.g., MMP7) (Miyamoto et al. 2004; Hemers et al. 2005) and ADAMs (e.g., ADAM28) (Mochizuki et al. 2004). MMP7 was also shown to cleave pro-HB-EGF to generate mature HB-EGF, which promotes cell survival by activating the receptor tyrosine kinase ErbB4 (Lynch et al. 2007). Pericellular proteases additionally release cell membranebound precursors of growth factors. For example, ADAM17 mediates ectodomain shedding of TGF- $\alpha$ (Peschon et al. 1998), and MMP2, MMP9, and cathepsin B mediate the release of TGF- $\beta$ (Yu and Stamenkovic 2000; Yin et al. 2012). Proteolytic processing is required for different growth factors to regulate their receptor specificity and activity. While the PDGF ligands A and B are secreted as active heterodimers or homodimers, PDGF ligands $\mathrm{C}$ and D are secreted as latent homodimers that require proteolytic activation (Li et al. 2000; Bergsten et al. 2001). tPA, uPA, and matriptase have been shown to proteolytically activate PDGF-C and PDGF-D (Hurst et al. 2012). Pericellular activation of HGF is mediated by the serine proteases matriptase and hepsin (Owen et al. 2010).

Besides the modulation of growth factor bioavailability, pericellular proteases are also known to regulate tumor cell survival via proapoptotic and anti-apoptotic functions. Proteolytic processing of the Fas ligand is an interesting example in this context, as it demonstrates that cleavage of the same substrate can either induce apoptosis or protect cells from apoptosis. Release of soluble Fas ligand (sFasL) from the cell surface induces death in adjacent cells upon binding to Fas. MMP3 and MMP7 (VargoGogola et al. 2002) as well as ADAM10 (Schulte et al. 2007) are known to release sFasL, which leads to induction of apoptosis in Fas-expressing epithelial cells (Powell et al. 1999). Interestingly, plasmin was recently shown to suppress brain metastasis by converting membrane-bound FasL on the surface of astrocytes to sFasL, which resulted in cancer cell killing. This cell death mechanism can be counteracted by inhibitory serpins, which are substantially up-regulated in breast cancer cells that successfully colonize the brain (Valiente et al. 2014). However, sFasL was also shown to protect tumor cells from chemotherapyinduced cytotoxicity (Mitsiades et al. 2001). The controversy regarding the biological activity of sFasL may be explained by the generation of distinct forms of sFasL as a result of proteolytic cleavage at specific sequences (Vargo-Gogola et al. 2002).

\section{Angiogenesis}

Angiogenesis requires degradation of the vascular basement membrane and remodeling of the ECM in order to allow endothelial cells to migrate and invade into the surrounding tissue (Fig. 3D). Invasion of endothelial cells into the ECM during capillary sprouting is mediated by different pericellular proteases, including MMPs (Ghajar et al. 2008), ADAMs, and cathepsins (Cavallo-Medved et al. 2009). MT1-MMP has been identified as the one of the most potent fibrinolytic and collagenolytic endothe- lial cell-derived MMPs during capillary sprouting (Hiraoka et al. 1998; Karagiannis and Popel 2006), and its expression is largely confined to the sprouting tips of neocapillary structures through interaction of endothelial cells with vascular smooth muscle cells (Yana et al. 2007). Proteolytic processing of ECM components leads to the exposure of "matricryptic" sites (Davis et al. 2000) such as the RGD motif, which is present in collagens, vitronectin, and osteopontin (Ruoslahti 1996). Exposed RGD motifs can bind $\alpha 5 \beta 1$ or $\alpha \nu \beta 3 / \alpha \nu \beta 5$ integrins, thus affecting endothelial cell adhesion, migration, and survival. For example, cleavage of collagen IV by MMP2 exposes a cryptic $\alpha \nu \beta 3$-binding site. Blockage of this binding site with an antibody disrupts integrin-dependent endothelial cell interactions and inhibits angiogenesis and tumor growth (Xu et al. 2001).

Vascular endothelial growth factor (VEGF) is a critical angiogenic growth factor that is subject to differential splicing, resulting in secretion of distinct isoforms that regulate the phenotype and efficacy of vascular sprouting (Carmeliet 2000). VEGF isoforms that contain C-terminal motifs (i.e., VEGF188 and VEGF164) show increased binding to heparin and HSPGs (Houck et al. 1992). The function of the different VEGF isoforms is regulated via their spatial distribution (Ruhrberg et al. 2002) and isoform-specific receptor binding on the surface of endothelial cells (Mac Gabhann and Popel 2008). VEGF isoform spatial distribution is mediated by both interactions with HSPGs in the ECM and proteases such as plasmin and a subset of MMPs that can cleave ECM components and the C-terminal regions of VEGF to release the biologically active growth factor from the ECM (Baker et al. 2000; Bergers et al. 2000; Lee et al. 2005; Hawinkels et al. 2008; Lederle et al. 2010). Binding to HSPGs can reduce the effective diffusivity of the isoform, thus altering the spatial distribution, which has important effects on vascular patterning. Larger isoforms give rise to sprouts that have enhanced filopodial directionality and vessels with greater branching density and smaller diameter, while shorter isoforms (i.e., VEGF120) promote vessels with lower branching density and larger diameter (Vempati et al. 2011). Importantly, proteolytic release via VEGF cleavage resembles secretion of shorter isoforms. For example, MMP9-mediated release of VEGF enhances VEGFR2 binding in quiescent vasculature by increasing diffusible VEGF levels, which activates tumor progression through angiogenic switching (Bergers et al. 2000). In contrast to VEGF release via cleavage of the C-terminal HB domain, cleavage of HSPGs and ECM components by proteases or heparanases releases intact, full-length VEGF.

The generation of biologically active fragments of ECM molecules, termed matrikines, is another important mechanism by which proteases regulate angiogenesis (Bellon et al. 2004; Monboisse et al. 2014). The majority of matrikines, such as angiostatin, arresten, canstatin, and tumstatin, exert anti-angiogenic functions by reducing endothelial cell proliferation. Cleavage of plasminogen by MMP2, MMP3, MMP7, MMP9, MMP12, and MMP19 generates angiostatin (Patterson and Sang 1997; Cornelius et al. 1998; Lijnen et al. 1998; Moses and O'Reilly 2003; Brauer et al. 2011), and 
endostatin is generated through cleavage of collagen XVIII by MMP3, MMP9, and MMP13 (Ma et al. 2007; Bendrik et al. 2010; Fukuda et al. 2011). Besides MMPs, different cathepsin family members, including the cysteine cathepsins L and S (Felbor et al. 2000; Veillard et al. 2011) and the aspartic cathepsin E (Shin et al. 2007), have been shown to generate endostatin from collagen XVIII. Conversely, Wang et al. (2006) proposed that cathepsin S promotes angiogenesis by degradation of the anti-angiogenic peptides canstatin and arresten and generation of proangiogenic fragments from laminin 5 in pancreatic neuroendocrine cancer (Fig. 3D).

\section{Inflammation and immune surveillance}

As discussed earlier, cytokines are potent endogenous regulators of chemokine and protease expression. In addition to the induction of protease expression, interactions between cytokines, proteases, and chemokines critically affect disease progression by orchestrating the recruitment of immune cells and modulating protumoral or anti-tumoral functions of the tumor microenvironment. Various pericellular proteases selectively cleave specific chemokines and cytokines, thereby affecting their bioavailability, receptor specificity, and chemotactic properties (Fig. 3E). CD26 (dipeptidylpeptidase IV), a membrane-bound serine protease expressed on lymphocytes, is highly selective for peptides that contain a proline at position 2 of the $\mathrm{N}$ terminus (De Meester et al. 1999). Interestingly, about one-third of human chemokines contain this motif. Indeed, CD26 cleaves many CCL and CXCL chemokines, which leads to their activation or inactivation (Moser et al. 2004). An interesting example that shows how proteolytic cleavage of a chemokine provides a mechanism for differential cell recruitment is the proteolytic processing of CCL5/RANTES by CD26. Truncated CCL5 has a lower chemotactic potency for monocytes and eosinophils and shows impaired binding to CCR 1 and CCR3 while remaining fully active in complex with CCR5. Thus, changes in receptor selectivity affect leukocyte recruitment based on chemokine receptor expression on infiltrating cells (Oravecz et al. 1997; Proost et al. 1998). While CD26mediated cleavage often activates chemokines (e.g., CXCL6, CXCL9, CXCL10, and CXCL11), MMP-mediated processing, on the other hand, can lead to inactivation or antagonistic activity of various CCL and CXCL chemokines (e.g., monocyte chemotactic protein-1 [MCP-1/CCL2] SDF-1) (Moser et al. 2004). Fewer cases have been reported in which MMPs activate chemokines. For example, MMP8 and MMP9 together with other proteases, including cathepsin L, render CXCL8 (IL-8) more active after N-terminal cleavage (Ohashi et al. 2003; Van Den Steen et al. 2003). Another interesting example that illustrates how proteolytic processing of cytokine receptors can impact tumor progression is generation of the soluble IL-6R (sIL-6R). In classical IL-6 signaling, the proinflammatory cytokine IL-6 binds to the membrane-bound IL-6R, whereas in transsignaling, IL6 acts via sIL-6R. IL-6 trans-signaling is linked to chronic inflammation and cancer, and the release of sIL-6R is mediated by ADAM10 and ADAM17 via receptor shedding (Chalaris et al. 2010). IL-6R trans-signaling has been shown to play a critical role in the onset and progression of colitis-associated cancer (Matsumoto et al. 2010).

In addition to the well-established role of proteases in chemokine and cytokine processing, several studies have provided insight into the impact of protease modulation of cellular responses during inflammation in the context of cancer. Proteases can regulate immune responses by affecting proliferation and survival of immune cell populations or inhibiting or enhancing protumor or antitumor responses. MMPs are critical modulators of T-cell proliferation and polarization. MMP9 can cleave IL-2R $\alpha$ and thereby suppress proliferation of $\mathrm{T}$ cells (Sheu et al. 2001). MMPs also activate TGF- $\beta$, which is an important inhibitor of the anti-tumor T-cell response (Gorelik and Flavell 2001). The balance of protumorigenic and antitumorigenic immune responses is based on the presence or absence of Th1 cytokines (e.g., IFN- $\gamma$, IL-2, or IL-12) or Th2 cytokines (e.g., IL-4 or IL-13) as well as expression of their cognate receptors. Skewing the immune response toward a type 2 response is often associated with tumor promotion (Mantovani and Locati 2013). MMP2 can act as an endogenous type 2 conditioner through type 1 interferon receptor degradation and may thus play a tumor-promoting role in melanoma (Godefroy et al. 2011). Other important proteolytic cleavage events that were proposed to be involved in tumor cell evasion of immune surveillance include MMP9-dependent shedding of the adhesion molecule ICAM-1 (Fiore et al. 2002) and MICA (MHC class I chain-related molecule A) (Sun et al. 2011), a ligand for the activating immunoreceptor NKG2D (natural killer group 2, member D). Shedding of ICAM-1 and MICA was found to augment tumor cell resistance to natural killer cell-mediated cytotoxicity. In addition, MMP9, ADAM10, and ADAM17 were also shown to shed MICA and MICB from different human tumor cell types, including breast, pancreatic, and prostate cancers (Chitadze et al. 2013). These examples illustrate the complexity of protease function in not only orchestrating immune cell recruitment but also modifying leukocyte activation and polarization. Collectively, protease-mediated chemokine and chemokine receptor processing plays a central role in skewing cancer-associated inflammation toward tumor-promoting or anti-tumor immune responses (Fig. 3E).

\section{Therapeutic strategies for targeting proteases in cancer}

Clinical trials conducted with broad-spectrum MMP inhibitors (MMPIs) over a decade ago yielded disappointing results. Reasons for the failure of MMPI trials have been discussed extensively elsewhere (Coussens et al. 2002; Overall and Lopez-Otin 2002). One important paradigm shift that has occurred in the past decade is the realization that individual protease family members exert highly specific functions that can be either tumor-promoting or tumor-suppressive. Based on these findings, new therapeutic strategies have been developed that aim to target tumor-promoting functions of individual proteases without deregulating normal biological processes or blocking 
tumor-suppressive functions of proteases. The first therapeutic applications of MMPIs involved delivering their endogenous inhibitors, TIMPs. However, protein-based treatments are difficult to administer and can show poor pharmacokinetics. Moreover, TIMPs inhibit a broad range of MMPs as well as some ADAMs and ADAMTS metalloproteinases.

Alternative approaches sought to change the ratio of proteases to protease inhibitors or restrict the inhibitory specificities of individual proteases through engineered protease inhibitors, specifically TIMPs. Lee et al. (2003) engineered TIMPs through mutagenesis strategies that show improved binding affinity for the target protease. Another strategy to direct TIMP activity to the plasma membrane used constructs in which TIMPs are fused to GPI anchors. Human TIMP-1 fused to a GPI anchor shifted the activity of TIMP-1 from the ECM to the cell surface, which resulted in induction of apoptosis and reduced proliferation of renal cell carcinoma cells (Notohamiprodjo et al. 2012). In addition to approaches that aim to improve the selectivity of inhibitors (Cuniasse et al. 2005) or neutralizing antibodies (Lund et al. 2011) against individual proteases, alternative strategies that target regulatory mechanisms, such as inhibition of NHE1 to prevent acidification of the extracellular environment (Kumar et al. 2009; Yang et al. 2010) or neutralizing inducers of protease expression such as CD147 (Dean et al. 2009), have been proposed.

Given the accumulating evidence that some functions of proteases in cancer can actually be independent of their proteolytic activity (Strongin 2010; Akkari et al. 2014), noncatalytic targeting of proteases may represent an innovative strategy to overcome certain limitations of inhibiting the catalytic site of proteases. On the other hand, protease catalytic functions can also be exploited for gene therapy or prodrug activation (Weidle et al. 2014). One approach involves the generation of protease-activatable retroviral vectors that show selective and highly efficient transduction of MMP-rich target cells in a heterogenous cell population, such as MMP-high tumors in xenograft models (Peng et al. 1999). Another concept that takes advantage of protease overexpression in malignant tumors is based on the activation of prodrugs, which is also important for limiting toxicity to normal cells. One example of this strategy involved generation of a mutated anthrax toxin-protective antigen, in which the furin cleavage site that is involved in lethal factor activation was replaced by sequences that are selectively cleaved by MMPs (Liu et al. 2000), thus restricting the activation of the prodrug to the surface of tumor cells with high MMP activity. More recent approaches have included generating a masked cytotoxic agent (puromycin, which is sequentially activated by histone deacetylase and cathep$\sin$ L) to target activity to cancer cells expressing high levels of both enzymes (Ueki et al. 2013). A related strategy to limit toxicity took advantage of legumain proteasemediated release of doxorubicin-containing liposomal nanoparticles to render them cell-permeable. Given that legumain is highly expressed in both cancer cells and macrophages, this enabled selective uptake of the cytotoxic drug by both cell types within the tumor microenviron- ment (Liu et al. 2014). Finally, small molecule inhibitors have been developed for the different catalytic classes discussed in this review, and several of these agents are in clinical trials or FDA-approved, as in the case of proteasome inhibitors (Turk 2006; Fingleton 2007; Palermo and Joyce 2008; Drag and Salvesen 2010; Seidah and Prat 2012; Crawford and Irvine 2013).

\section{Conclusions and perspectives}

Pericellular proteases have long been recognized as critical regulators of cancer progression and metastasis. Numerous studies in the past several years have now provided critical mechanistic insights into the functional diversity of pericellular proteases in cancer, as we discussed here. One key take-home message is that of the inherent complexity of proteolysis in both normal physiology and cancer. This is exemplified by the concept of the protease web; a highly interconnected network of interactions between proteases, their endogenous inhibitors, interacting partners, and substrates (auf dem Keller et al. 2007; Fortelny et al. 2014). Additional layers of regulation are conferred by transcriptional and epigenetic mechanisms, miRNA-mediated regulation, post-translational modifications, and subcellular localization, among others. However, as we discussed here, there are at least as many means to override these regulatory mechanisms in cancer, ranging from tumor cell-intrinsic alterations (including mutations, gene amplifications, and activation by different oncogenic signaling cascades) to aberrant paracrine signaling loops between different cell types within the microenvironment, which can further amplify pericellular proteolysis. Unraveling the complexity of these intricate pathways will continue to provide key insights into how proteases can profoundly influence essentially every step in the invasion-metastasis cascade (Fig. 3).

From a translational perspective, the failure of broadspectrum MMPI trials in the 1990s unfortunately resulted in a general assumption that MMPs as well as other proteases are not attractive therapeutic targets in cancer. We would propose that future efforts to target proteases consider their position within the proteolytic web, and thus rather than inhibiting entire families of enzymes, often with opposing functions in cancer, one would instead identify and target the key nodes or hubs within the network. This type of approach will undoubtedly be challenging, in part because it requires a new perspective in considering how proteases function within an interconnected biological framework rather than as individual enzymes. Nonetheless, recent advances, including mathematical modeling (Fortelny et al. 2014) and analysis of complex tumorstroma interactions in different metastatic microenvironments (Sevenich et al. 2014), represent important first steps in this endeavor. When coupled with analyses of target substrates and matrix molecules in cell types and tissues of interest (Naba et al. 2012, 2014a,b), this should enable a sophisticated and integrated perspective of the cancer degradome, which will be critical for designing appropriate and effective therapeutic strategies in the future. 


\section{Acknowledgments}

We apologize to the researchers whose work is not cited due to space limitations. We thank members of the Joyce laboratory for discussion on this topic. Research in the Joyce laboratory is supported by the National Institutes of Health (CA181355 and CA148967), American Cancer Society (RSG-12-076-01-LIB), and the Breast Cancer Research Foundation. L.S. was supported by a postdoctoral fellowship from the Deutsche Forschungsgemeinschaft (SE2234/1-1).

\section{References}

Affara NI, Andreu P, Coussens LM. 2009. Delineating protease functions during cancer development. Methods Mol Biol 539: 1-32.

Akkari L, Gocheva V, Kester JC, Hunter KE, Quick ML, Sevenich L, Wang H-W, Peters C, Tang LH, Klimstra D, et al. 2014. Distinct functions of macrophage- and cancer cell-derived cathepsin $\mathrm{Z}$ combine to promote tumor malignancy via interactions with the extracellular matrix. Genes Dev 28: 2134-2150.

Almeida PC, Nantes IL, Rizzi CC, Judice WA, Chagas JR, Juliano L, Nader HB, Tersariol IL. 1999. Cysteine proteinase activity regulation: a possible role of heparin and heparin-like glycosaminoglycans. I Biol Chem 274: 30433-30438.

Almeida PC, Nantes IL, Chagas JR, Rizzi CC, Faljoni-Alario A, Carmona E, Juliano L, Nader HB, Tersariol IL. 2001. Cathep$\sin \mathrm{B}$ activity regulation. Heparin-like glycosaminogylcans protect human cathepsin B from alkaline $\mathrm{pH}$-induced inactivation. J Biol Chem 276: 944-951.

Antalis TM, Bugge TH, Wu Q. 2011. Membrane-anchored serine proteases in health and disease. Prog Mol Biol Transl Sci 99: $1-50$.

Artym VV, Zhang Y, Seillier-Moiseiwitsch F, Yamada KM, Mueller SC. 2006. Dynamic interactions of cortactin and membrane type 1 matrix metalloproteinase at invadopodia: defining the stages of invadopodia formation and function. Cancer Res 66: 3034-3043.

auf dem Keller U, Doucet A, Overall CM. 2007. Protease research in the era of systems biology. Biol Chem 388: 1159-1162.

Baker EA, Bergin FG, Leaper DJ. 2000. Plasminogen activator system, vascular endothelial growth factor, and colorectal cancer progression. Mol Pathol 53: 307-312.

Baxter RC. 2014. IGF binding proteins in cancer: mechanistic and clinical insights. Nat Rev Cancer 14: 329-341.

Bellon G, Martiny L, Robinet A. 2004. Matrix metalloproteinases and matrikines in angiogenesis. Crit Rev Oncol Hematol 49: 203-220.

Bendrik C, Karlsson L, Dabrosin C. 2010. Increased endostatin generation and decreased angiogenesis via MMP-9 by tamoxifen in hormone dependent ovarian cancer. Cancer Lett 292: 32-40.

Bergers G, Brekken R, McMahon G, Vu TH, Itoh T, Tamaki K, Tanzawa K, Thorpe P, Itohara S, Werb Z, et al. 2000. Matrix metalloproteinase- 9 triggers the angiogenic switch during carcinogenesis. Nat Cell Biol 2: 737-744.

Bergsten E, Uutela M, Li X, Pietras K, Ostman A, Heldin CH, Alitalo K, Eriksson U. 2001. PDGF-D is a specific, proteaseactivated ligand for the PDGFß-receptor. Nat Cell Biol 3: 512-516.

Bharadwaj A, Bydoun M, Holloway R, Waisman D. 2013. Annexin A2 heterotetramer: structure and function. Int J Mol Sci 14: 6259-6305.

Blasi F, Sidenius N. 2010. The urokinase receptor: focused cell surface proteolysis, cell adhesion and signaling. FEBS Lett 584: 1923-1930.
Bourguignon LY, Singleton PA, Diedrich F, Stern R, Gilad E. 2004. CD44 interaction with $\mathrm{Na}^{+}-\mathrm{H}^{+}$exchanger (NHE1) creates acidic microenvironments leading to hyaluronidase2 and cathepsin B activation and breast tumor cell invasion. J Biol Chem 279: 26991-27007.

Bracken CP, Li X, Wright JA, Lawrence D, Pillman KA, Salmanidis M, Anderson MA, Dredge BK, Gregory PA, Tsykin A, et al. 2014. Genome-wide identification of miR200 targets reveals a regulatory network controlling cell invasion. EMBO J 33: 2040-2056.

Brauer R, Beck IM, Roderfeld M, Roeb E, Sedlacek R. 2011. Matrix metalloproteinase-19 inhibits growth of endothelial cells by generating angiostatin-like fragments from plasminogen. BMC Biochem 12: 38.

Brisson L, Reshkin SJ, Gore J, Roger S. 2012. pH regulators in invadosomal functioning: proton delivery for matrix tasting. Eur J Cell Biol 91: 847-860.

Brix K, Dunkhorst A, Mayer K, Jordans S. 2008. Cysteine cathepsins: cellular roadmap to different functions. Biochimie 90: 194-207.

Brooks PC, Stromblad S, Sanders LC, von Schalscha TL, Aimes RT, Stetler-Stevenson WG, Quigley JP, Cheresh DA. 1996. Localization of matrix metalloproteinase MMP-2 to the surface of invasive cells by interaction with integrin $\alpha \mathrm{v} \beta 3$. Cell 85: 683693.

Brouxhon SM, Kyrkanides S, Teng X, Athar M, Ghazizadeh S, Simon M, O'Banion MK, Ma L. 2014. Soluble E-cadherin: a critical oncogene modulating receptor tyrosine kinases, MAPK and PI3K/Akt/mTOR signaling. Oncogene 33: 225235.

Bubendorf L, Schopfer A, Wagner U, Sauter G, Moch H, Willi N, Gasser TC, Mihatsch MJ. 2000. Metastatic patterns of prostate cancer: an autopsy study of 1,589 patients. Hum Pathol 31: 578-583.

Buschman MD, Bromann PA, Cejudo-Martin P, Wen F, Pass I, Courtneidge SA. 2009. The novel adaptor protein Tks4 (SH3PXD2B) is required for functional podosome formation. Mol Biol Cell 20: 1302-1311.

Cai Z, Yang F, Yu L, Yu Z, Jiang L, Wang Q, Yang Y, Wang L, Cao X, Wang J. 2012. Activated T cell exosomes promote tumor invasion via Fas signaling pathway. I Immunol 188: 5954-5961.

Calon A, Espinet E, Palomo-Ponce S, Tauriello DV, Iglesias M, Cespedes MV, Sevillano M, Nadal C, Jung P, Zhang XH, et al. 2012. Dependency of colorectal cancer on a TGF- $\beta$-driven program in stromal cells for metastasis initiation. Cancer Cell 22: 571-584.

Carmeliet P. 2000. Mechanisms of angiogenesis and arteriogenesis. Nat Med 6: 389-395.

Cavallo-Medved D, Sloane BF. 2003. Cell-surface cathepsin B: understanding its functional significance. Curr Top Dev Biol 54: 313-341.

Cavallo-Medved D, Dosescu J, Linebaugh BE, Sameni M, Rudy D, Sloane BF. 2003. Mutant K-ras regulates cathepsin B localization on the surface of human colorectal carcinoma cells. Neoplasia 5: 507-519.

Cavallo-Medved D, Mai J, Dosescu J, Sameni M, Sloane BF. 2005. Caveolin-1 mediates the expression and localization of cathepsin B, pro-urokinase plasminogen activator and their cell-surface receptors in human colorectal carcinoma cells. J Cell Sci 118: 1493-1503.

Cavallo-Medved D, Rudy D, Blum G, Bogyo M, Caglic D, Sloane BF. 2009. Live-cell imaging demonstrates extracellular matrix degradation in association with active cathepsin $B$ in caveolae of endothelial cells during tube formation. Exp Cell Res 315: 1234-1246. 
Chabottaux V, Ricaud S, Host L, Blacher S, Paye A, Thiry M, Garofalakis A, Pestourie C, Gombert K, Bruyere F, et al. 2009. Membrane-type 4 matrix metalloproteinase (MT4-MMP) induces lung metastasis by alteration of primary breast tumour vascular architecture. J Cell Mol Med 13: 4002-4013.

Chalaris A, Gewiese J, Paliga K, Fleig L, Schneede A, Krieger K, Rose-John S, Scheller J. 2010. ADAM17-mediated shedding of the IL6R induces cleavage of the membrane stub by $\lambda$-secretase. Biochim Biophys Acta 1803: 234-245.

Chitadze G, Lettau M, Bhat J, Wesch D, Steinle A, Furst D, Mytilineos J, Kalthoff H, Janssen O, Oberg HH, et al. 2013. Shedding of endogenous MHC class I-related chain molecules A and B from different human tumor entities: heterogeneous involvement of the 'a disintegrin and metalloproteases' 10 and 17. Int J Cancer 133: 1557-1566.

Collette J, Bocock JP, Ahn K, Chapman RL, Godbold G, Yeyeodu S, Erickson AH. 2004. Biosynthesis and alternate targeting of the lysosomal cysteine protease cathepsin L. Int Rev Cytol 241: $1-51$.

Cornelius LA, Nehring LC, Harding E, Bolanowski M, Welgus HG, Kobayashi DK, Pierce RA, Shapiro SD. 1998. Matrix metalloproteinases generate angiostatin: effects on neovascularization. J Immunol 161: 6845-6852.

Coussens LM, Fingleton B, Matrisian LM. 2002. Matrix metalloproteinase inhibitors and cancer: trials and tribulations. Science 295: 2387-2392.

Crawford LJ, Irvine AE. 2013. Targeting the ubiquitin proteasome system in haematological malignancies. Blood Rev 27: 297-304.

Cuniasse P, Devel L, Makaritis A, Beau F, Georgiadis D, Matziari M, Yiotakis A, Dive V. 2005. Future challenges facing the development of specific active-site-directed synthetic inhibitors of MMPs. Biochimie 87: 393-402.

Dalmay T, Edwards DR. 2006. MicroRNAs and the hallmarks of cancer. Oncogene 25: 6170-6175.

Davis GE, Bayless KJ, Davis MJ, Meininger GA. 2000. Regulation of tissue injury responses by the exposure of matricryptic sites within extracellular matrix molecules. Am I Pathol 156: 1489-1498.

Dean NR, Newman JR, Helman EE, Zhang W, Safavy S, Weeks DM, Cunningham M, Snyder LA, Tang Y, Yan L, et al. 2009. Anti-EMMPRIN monoclonal antibody as a novel agent for therapy of head and neck cancer. Clin Cancer Res 15: 40584065.

De Meester I, Korom S, Van Damme J, Scharpe S. 1999. CD26, let it cut or cut it down. Immunol Today 20: 367-375.

Dennemarker J, Lohmuller T, Mayerle J, Tacke M, Lerch MM, Coussens LM, Peters C, Reinheckel T. 2010. Deficiency for the cysteine protease cathepsin $\mathrm{L}$ promotes tumor progression in mouse epidermis. Oncogene 29: 1611-1621.

Depner S, Lederle W, Gutschalk C, Linde N, Zajonz A, Mueller MM. 2014. Cell type specific interleukin-6 induced responses in tumor keratinocytes and stromal fibroblasts are essential for invasive growth. Int J Cancer 135: 551-562.

Drag M, Salvesen GS. 2010. Emerging principles in proteasebased drug discovery. Nat Rev Drug Discov 9: 690-701.

Duffy MJ. 1996. Proteases as prognostic markers in cancer. Clin Cancer Res 2: 613-618.

Dyczynska E, Syta E, Sun D, Zolkiewska A. 2008. Breast cancerassociated mutations in metalloprotease disintegrin ADAM12 interfere with the intracellular trafficking and processing of the protein. Int J Cancer 122: 2634-2640.

Edwards DR, Handsley MM, Pennington CJ. 2008. The ADAM metalloproteinases. Mol Aspects Med 29: 258-289.

Eustace BK, Sakurai T, Stewart JK, Yimlamai D, Unger C, Zehetmeier C, Lain B, Torella C, Henning SW, Beste G, et al. 2004. Functional proteomic screens reveal an essential extracellular role for hsp90 $\alpha$ in cancer cell invasiveness. Nat Cell Biol 6: 507-514.

Felbor U, Dreier L, Bryant RA, Ploegh HL, Olsen BR, Mothes W. 2000. Secreted cathepsin L generates endostatin from collagen XVIII. EMBO J 19: 1187-1194.

Feng S, Cen J, Huang Y, Shen H, Yao L, Wang Y, Chen Z. 2011. Matrix metalloproteinase-2 and -9 secreted by leukemic cells increase the permeability of blood-brain barrier by disrupting tight junction proteins. PLOS ONE 6: e20599.

Fingleton B. 2007. Matrix metalloproteinases as valid clinical targets. Curr Pharm Des 13: 333-346.

Fiore E, Fusco C, Romero P, Stamenkovic I. 2002. Matrix metalloproteinase 9 (MMP-9/gelatinase B) proteolytically cleaves ICAM-1 and participates in tumor cell resistance to natural killer cell-mediated cytotoxicity. Oncogene 21: 5213-5223.

Fischer A. 1946. Mechanism of the proteolytic activity of malignant tissue cells. Nature 157: 442.

Fortelny N, Cox JH, Kappelhoff R, Starr AE, Lange PF, Pavlidis P, Overall CM. 2014. Network analyses reveal pervasive functional regulation between proteases in the human protease web. PLoS Biol 12: e1001869.

Friedrich R, Fuentes-Prior P, Ong E, Coombs G, Hunter M, Oehler R, Pierson D, Gonzalez R, Huber R, Bode W, et al. 2002. Catalytic domain structures of MT-SP1/matriptase, a matrix-degrading transmembrane serine proteinase. I Biol Chem 277: 2160-2168.

Fukuda H, Mochizuki S, Abe H, Okano HJ, Hara-Miyauchi C, Okano H, Yamaguchi N, Nakayama M, D'Armiento I, Okada Y. 2011. Host-derived MMP-13 exhibits a protective role in lung metastasis of melanoma cells by local endostatin production. $\mathrm{Br}$ J Cancer 105: 1615-1624.

Gabison EE, Hoang-Xuan T, Mauviel A, Menashi S. 2005. EMMPRIN/CD147, an MMP modulator in cancer, development and tissue repair. Biochimie 87: 361-368.

Gabriely G, Wurdinger T, Kesari S, Esau CC, Burchard J, Linsley PS, Krichevsky AM. 2008. MicroRNA 21 promotes glioma invasion by targeting matrix metalloproteinase regulators. Mol Cell Biol 28: 5369-5380.

Gallagher FA, Kettunen MI, Day SE, Hu DE, Ardenkjaer-Larsen JH, Zandt R, Jensen PR, Karlsson M, Golman K, Lerche MH, et al. 2008. Magnetic resonance imaging of $\mathrm{pH}$ in vivo using hyperpolarized 13C-labelled bicarbonate. Nature 453: 940-943.

Gerweck LE, Seetharaman K. 1996. Cellular pH gradient in tumor versus normal tissue: potential exploitation for the treatment of cancer. Cancer Res 56: 1194-1198.

Ghajar CM, George SC, Putnam AJ. 2008. Matrix metalloproteinase control of capillary morphogenesis. Crit Rev Eukaryot Gene Expr 18: 251-278.

Gocheva V, Zeng W, Ke D, Klimstra D, Reinheckel T, Peters C, Hanahan D, Joyce JA. 2006. Distinct roles for cysteine cathepsin genes in multistage tumorigenesis. Genes Dev 20: 543-556.

Gocheva V, Wang HW, Gadea BB, Shree T, Hunter KE, Garfall AL, Berman T, Joyce JA. 2010. IL-4 induces cathepsin protease activity in tumor-associated macrophages to promote cancer growth and invasion. Genes Dev 24: 241-255.

Godefroy E, Manches O, Dreno B, Hochman T, Rolnitzky L, Labarriere N, Guilloux Y, Goldberg J, Jotereau F, Bhardwaj N. 2011. Matrix metalloproteinase-2 conditions human dendritic cells to prime inflammatory $\mathrm{T}(\mathrm{H}) 2$ cells via an IL-12and OX40L-dependent pathway. Cancer Cell 19: 333-346.

Gorelik L, Flavell RA. 2001. Immune-mediated eradication of tumors through the blockade of transforming growth factor$\beta$ signaling in T cells. Nat Med 7: 1118-1122. 
Gould CM, Courtneidge SA. 2014. Regulation of invadopodia by the tumor microenvironment. Cell Adhes Migr 8: 226-235.

Grabowska MM, Sandhu B, Day ML. 2012. EGF promotes the shedding of soluble E-cadherin in an ADAM10-dependent manner in prostate epithelial cells. Cell Signal 24: 532-538.

Grass GD, Bratoeva M, Toole BP. 2012. Regulation of invadopodia formation and activity by CD147. J Cell Sci 125: 777788.

Grass GD, Tolliver LB, Bratoeva M, Toole BP. 2013. CD147, CD44, and the epidermal growth factor receptor (EGFR) signaling pathway cooperate to regulate breast epithelial cell invasiveness. J Biol Chem 288: 26089-26104.

Guo Y, Xu F, Lu T, Duan Z, Zhang Z. 2012. Interleukin-6 signaling pathway in targeted therapy for cancer. Cancer Treat Rev 38: 904-910.

Gupta GP, Nguyen DX, Chiang AC, Bos PD, Kim JY, Nadal C, Gomis RR, Manova-Todorova K, Massague J. 2007. Mediators of vascular remodelling co-opted for sequential steps in lung metastasis. Nature 446: 765-770.

Hakulinen J, Sankkila L, Sugiyama N, Lehti K, Keski-Oja J. 2008. Secretion of active membrane type 1 matrix metalloproteinase (MMP-14) into extracellular space in microvesicular exosomes. J Cell Biochem 105: 1211-1218.

Hawinkels LJ, Zuidwijk K, Verspaget HW, de Jonge-Muller ES, van Duijn W, Ferreira V, Fontijn RD, David G, Hommes DW, Lamers CB, et al. 2008. VEGF release by MMP-9 mediated heparan sulphate cleavage induces colorectal cancer angiogenesis. Eur J Cancer 44: 1904-1913.

Hawinkels LJ, Paauwe M, Verspaget HW, Wiercinska E, van der Zon JM, van der Ploeg K, Koelink PJ, Lindeman JH, Mesker $\mathrm{W}$, ten Dijke P, et al. 2014. Interaction with colon cancer cells hyperactivates TGF- $\beta$ signaling in cancer-associated fibroblasts. Oncogene 33: 97-107.

Hemers E, Duval C, McCaig C, Handley M, Dockray GJ, Varro A. 2005. Insulin-like growth factor binding protein-5 is a target of matrix metalloproteinase-7: implications for epithelialmesenchymal signaling. Cancer Res 65: 7363-7369.

Hiraoka N, Allen E, Apel IJ, Gyetko MR, Weiss SJ. 1998. Matrix metalloproteinases regulate neovascularization by acting as pericellular fibrinolysins. Cell 95: 365-377.

Hood JD, Cheresh DA. 2002. Role of integrins in cell invasion and migration. Nat Rev Cancer 2: 91-100.

Houck KA, Leung DW, Rowland AM, Winer J, Ferrara N. 1992. Dual regulation of vascular endothelial growth factor bioavailability by genetic and proteolytic mechanisms. I Biol Chem 267: 26031-26037.

Huai Q, Mazar AP, Kuo A, Parry GC, Shaw DE, Callahan J, Li Y, Yuan C, Bian C, Chen L, et al. 2006. Structure of human urokinase plasminogen activator in complex with its receptor. Science 311: 656-659.

Huguenin M, Muller EJ, Trachsel-Rosmann S, Oneda B, Ambort D, Sterchi EE, Lottaz D. 2008. The metalloprotease meprin $\beta$ processes E-cadherin and weakens intercellular adhesion. PLOS ONE 3: e2153.

Hurst NJ Jr, Najy AJ, Ustach CV, Movilla L, Kim HR. 2012. Platelet-derived growth factor-C (PDGF-C) activation by serine proteases: implications for breast cancer progression. Biochem J 441: 909-918.

Juncker-Jensen A, Deryugina EI, Rimann I, Zajac E, Kupriyanova TA, Engelholm LH, Quigley JP. 2013. Tumor MMP-1 activates endothelial PAR1 to facilitate vascular intravasation and metastatic dissemination. Cancer Res 73: 4196-4211.

Kaminski A, Hahne JC, Haddouti E-M, Florin A, Wellmann A, Wernert N. 2006. Tumour-stroma interactions between metastatic prostate cancer cells and fibroblasts. Int I Mol Med 18: 941-950.
Karagiannis ED, Popel AS. 2006. Distinct modes of collagen type I proteolysis by matrix metalloproteinase (MMP) 2 and membrane type I MMP during the migration of a tip endothelial cell: insights from a computational model. $I$ Theor Biol 238: 124-145.

Kenig S, Alonso MB, Mueller MM, Lah TT. 2010. Glioblastoma and endothelial cells cross-talk, mediated by SDF-1, enhances tumour invasion and endothelial proliferation by increasing expression of cathepsins B, S, and MMP-9. Cancer Lett 289: 53-61.

Kessenbrock K, Plaks V, Werb Z. 2010. Matrix metalloproteinases: regulators of the tumor microenvironment. Cell 141: $52-67$.

Kothari P, Pestana R, Mesraoua R, Elchaki R, Khan KM, Dannenberg AJ, Falcone DJ. 2014. IL-6-mediated induction of matrix metalloproteinase- 9 is modulated by JAK-dependent IL-10 expression in macrophages. J Immunol 192: 349357.

Kumar AP, Quake AL, Chang MK, Zhou T, Lim KS, Singh R, Hewitt RE, Salto-Tellez M, Pervaiz S, Clement MV. 2009. Repression of NHE1 expression by PPAR $\gamma$ activation is a potential new approach for specific inhibition of the growth of tumor cells in vitro and in vivo. Cancer Res 69: 86368644.

Lechner AM, Assfalg-Machleidt I, Zahler S, Stoeckelhuber M, Machleidt W, Jochum M, Nagler DK. 2006. RGD-dependent binding of procathepsin $X$ to integrin $\alpha \mathrm{v} \beta 3$ mediates celladhesive properties. J Biol Chem 281: 39588-39597.

Lederle W, Hartenstein B, Meides A, Kunzelmann H, Werb Z, Angel P, Mueller MM. 2010. MMP13 as a stromal mediator in controlling persistent angiogenesis in skin carcinoma. Carcinogenesis 31: 1175-1184.

Lee MH, Dodds P, Verma V, Maskos K, Knauper V, Murphy G. 2003. Tailoring tissue inhibitor of metalloproteinases-3 to overcome the weakening effects of the cysteine-rich domains of tumour necrosis factor- $\alpha$ converting enzyme. Biochem J 371: 369-376.

Lee S, Jilani SM, Nikolova GV, Carpizo D, Iruela-Arispe ML. 2005. Processing of VEGF-A by matrix metalloproteinases regulates bioavailability and vascular patterning in tumors. J Cell Biol 169: 681-691.

Leong HS, Robertson AE, Stoletov K, Leith SJ, Chin CA, Chien $\mathrm{AE}$, Hague MN, Ablack A, Carmine-Simmen $\mathrm{K}, \mathrm{McPherson}$ VA et al. 2014. Invadopodia are required for cancer cell extravasation and are a therapeutic target for metastasis. Cell Rep 8: 1558-1570.

Li L, Li H. 2013. Role of microRNA-mediated MMP regulation in the treatment and diagnosis of malignant tumors. Cancer Biol Ther 14: 796-805.

Li X, Ponten A, Aase K, Karlsson L, Abramsson A, Uutela M, Backstrom G, Hellstrom M, Bostrom H, Li H, et al. 2000. PDGF-C is a new protease-activated ligand for the PDGF $\alpha$-receptor. Nat Cell Biol 2: 302-309.

Li CM, Chen G, Dayton TL, Kim-Kiselak C, Hoersch S, Whittaker CA, Bronson RT, Beer DG, Winslow MM, Jacks T. 2013. Differential Tks5 isoform expression contributes to metastatic invasion of lung adenocarcinoma. Genes Dev 27: 1557-1567.

Lijnen HR, Ugwu F, Bini A, Collen D. 1998. Generation of an angiostatin-like fragment from plasminogen by stromelysin1 (MMP-3). Biochemistry 37: 4699-4702.

Lilja H, Ulmert D, Vickers AJ. 2008. Prostate-specific antigen and prostate cancer: prediction, detection and monitoring. Nat Rev Cancer 8: 268-278.

Lim M, Martinez T, Jablons D, Cameron R, Guo H, Toole B, Li JD, Basbaum C. 1998. Tumor-derived EMMPRIN (extracel- 
lular matrix metalloproteinase inducer) stimulates collagenase transcription through MAPK p38. FEBS Lett 441: 88-92.

Lingwood D, Simons K. 2010. Lipid rafts as a membraneorganizing principle. Science 327: 46-50.

Liou GY, Doppler H, Necela B, Krishna M, Crawford HC, Raimondo M, Storz P. 2013. Macrophage-secreted cytokines drive pancreatic acinar-to-ductal metaplasia through NF-кB and MMPs. J Cell Biol 202: 563-577.

Liu S, Netzel-Arnett S, Birkedal-Hansen H, Leppla SH. 2000. Tumor cell-selective cytotoxicity of matrix metalloproteinase-activated anthrax toxin. Cancer Res 60: 6061-6067.

Liu Z, Xiong M, Gong J, Zhang Y, Bai N, Luo Y, Li L, Wei Y, Liu $\mathrm{Y}$, Tan $\mathrm{X}$, et al. 2014. Legumain protease-activated TATliposome cargo for targeting tumours and their microenvironment. Nat Commun 5: 4280.

Lochter A, Galosy S, Muschler J, Freedman N, Werb Z, Bissell MJ. 1997. Matrix metalloproteinase stromelysin-1 triggers a cascade of molecular alterations that leads to stable epithelial-to-mesenchymal conversion and a premalignant phenotype in mammary epithelial cells. I Cell Biol 139: 1861-1872.

Lopez-Otin C, Bond JS. 2008. Proteases: multifunctional enzymes in life and disease. J Biol Chem 283: 30433-30437.

Lopez-Otin C, Hunter T. 2010. The regulatory crosstalk between kinases and proteases in cancer. Nat Rev Cancer 10: 278-292.

Lu X, Wang Q, Hu G, Van Poznak C, Fleisher M, Reiss M, Massague J, Kang Y. 2009. ADAMTS1 and MMP1 proteolytically engage EGF-like ligands in an osteolytic signaling cascade for bone metastasis. Genes Dev 23: 1882-1894.

Lucas JM, Heinlein C, Kim T, Hernandez SA, Malik MS, True LD, Morrissey C, Corey E, Montgomery B, Mostaghel E et al. 2014. The androgen-regulated protease TMPRSS2 activates a proteolytic cascade involving components of the tumor microenvironment and promotes prostate cancer metastasis. Cancer Discov doi: 10.1158/2159-8290.CD-13-1010.

Lund IK, Illemann M, Thurison T, Christensen IJ, Hoyer-Hansen G. 2011. uPAR as anti-cancer target: evaluation of biomarker potential, histological localization, and antibody-based therapy. Curr Drug Targets 12: 1744-1760.

Lynch CC, Hikosaka A, Acuff HB, Martin MD, Kawai N, Singh RK, Vargo-Gogola TC, Begtrup JL, Peterson TE, Fingleton B, et al. 2005. MMP-7 promotes prostate cancer-induced osteolysis via the solubilization of RANKL. Cancer Cell 7: 485496.

Lynch CC, Vargo-Gogola T, Martin MD, Fingleton B, Crawford HC, Matrisian LM. 2007. Matrix metalloproteinase 7 mediates mammary epithelial cell tumorigenesis through the ErbB4 receptor. Cancer Res 67: 6760-6767.

Ma DH, Yao JY, Kuo MT, See LC, Lin KY, Chen SC, Chen JK, Chao AS, Wang SF, Lin KK. 2007. Generation of endostatin by matrix metalloproteinase and cathepsin from human limbocorneal epithelial cells cultivated on amniotic membrane. Invest Ophthalmol Vis Sci 48: 644-651.

Mac Gabhann F, Popel AS. 2008. Systems biology of vascular endothelial growth factors. Microcirculation 15: 715-738.

Major TC, Liang L, Lu X, Rosebury W, Bocan TM. 2002. Extracellular matrix metalloproteinase inducer (EMMPRIN) is induced upon monocyte differentiation and is expressed in human atheroma. Arterioscler Thromb Vasc Biol 22: 12001207.

Makowski GS, Ramsby ML. 1998. Binding of latent matrix metalloproteinase 9 to fibrin: activation via a plasmin-dependent pathway. Inflammation 22: 287-305.

Mantovani A, Locati M. 2013. Tumor-associated macrophages as a paradigm of macrophage plasticity, diversity, and polar- ization: lessons and open questions. Arterioscler Thromb Vasc Biol 33: 1478-1483.

Marrero-Diaz R, Bravo-Cordero J], Megias D, Garcia MA, Bartolome RA, Teixido J, Montoya MC. 2009. Polarized MT1-MMP-CD44 interaction and CD44 cleavage during cell retraction reveal an essential role for MT1-MMP in CD44-mediated invasion. Cell Motil Cytoskeleton 66: 48-61.

Mason SD, Joyce JA. 2011. Proteolytic networks in cancer. Trends Cell Biol 21: 228-237.

Mathews JA, Gibb DR, Chen BH, Scherle P, Conrad DH. 2010. CD23 Sheddase A disintegrin and metalloproteinase 10 (ADAM10) is also required for CD23 sorting into B cellderived exosomes. J Biol Chem 285: 37531-37541.

Matsumoto S, Hara T, Mitsuyama K, Yamamoto M, Tsuruta O, Sata M, Scheller J, Rose-John S, Kado S, Takada T. 2010. Essential roles of IL-6 trans-signaling in colonic epithelial cells, induced by the IL-6/soluble-IL-6 receptor derived from lamina propria macrophages, on the development of colitis-associated premalignant cancer in a murine model. J Immunol 184: 1543-1551.

McCready J, Sims JD, Chan D, Jay DG. 2010. Secretion of extracellular hsp90 $\alpha$ via exosomes increases cancer cell motility: a role for plasminogen activation. BMC Cancer 10: 294.

Minn AJ, Gupta GP, Siegel PM, Bos PD, Shu W, Giri DD, Viale A, Olshen AB, Gerald WL, Massague J. 2005. Genes that mediate breast cancer metastasis to lung. Nature 436: 518-524.

Mitsiades N, Yu WH, Poulaki V, Tsokos M, Stamenkovic I. 2001. Matrix metalloproteinase-7-mediated cleavage of Fas ligand protects tumor cells from chemotherapeutic drug cytotoxicity. Cancer Res 61: 577-581.

Miyamoto S, Yano K, Sugimoto S, Ishii G, Hasebe T, Endoh Y, Kodama K, Goya M, Chiba T, Ochiai A. 2004. Matrix metalloproteinase-7 facilitates insulin-like growth factor bioavailability through its proteinase activity on insulin-like growth factor binding protein 3. Cancer Res 64: 665-671.

Mochizuki S, Shimoda M, Shiomi T, Fujii Y, Okada Y. 2004. ADAM28 is activated by MMP-7 (matrilysin-1) and cleaves insulin-like growth factor binding protein-3. Biochem Biophys Res Commun 315: 79-84.

Mohamed MM, Sloane BF. 2006. Cysteine cathepsins: multifunctional enzymes in cancer. Nat Rev Cancer 6: 764-775.

Mohamed MM, Cavallo-Medved D, Rudy D, Anbalagan A, Moin K, Sloane BF. 2010. Interleukin-6 increases expression and secretion of cathepsin $\mathrm{B}$ by breast tumor-associated monocytes. Cell Physiol Biochem 25: 315-324.

Monboisse JC, Oudart JB, Ramont L, Brassart-Pasco S, Maquart FX. 2014. Matrikines from basement membrane collagens: a new anti-cancer strategy. Biochim Biophys Acta 1840: 2589-2598.

Moser B, Wolf M, Walz A, Loetscher P. 2004. Chemokines: multiple levels of leukocyte migration control. Trends Immunol 25: 75-84.

Moses MA, O'Reilly MS. 2003. Regulation of angiostatin mobilization by tumor-derived matrix metalloproteinase-2. Methods Mol Med 74: 375-390.

Murphy G. 2008. The ADAMs: signalling scissors in the tumour microenvironment. Nat Rev Cancer 8: 929-941.

Murphy DA, Courtneidge SA. 2011. The 'ins' and 'outs' of podosomes and invadopodia: characteristics, formation and function. Nat Rev Mol Cell Biol 12: 413-426.

Naba A, Clauser KR, Hoersch S, Liu H, Carr SA, Hynes RO. 2012. The matrisome: in silico definition and in vivo characterization by proteomics of normal and tumor extracellular matrices. Mol Cell Proteomics 11: M111.014647.

Naba A, Clauser KR, Lamar JM, Carr SA, Hynes RO. 2014a. Extracellular matrix signatures of human mammary carcinoma identify novel metastasis promoters. Elife 3: e01308. 
Naba A, Clauser KR, Whittaker CA, Carr SA, Tanabe KK, Hynes RO. 2014b. Extracellular matrix signatures of human primary metastatic colon cancers and their metastases to liver. BMC Cancer 14: 518.

Nagase H, Visse R, Murphy G. 2006. Structure and function of matrix metalloproteinases and TIMPs. Cardiovasc Res 69: 562-573.

Najy AJ, Day KC, Day ML. 2008. The ectodomain shedding of E-cadherin by ADAM15 supports ErbB receptor activation. J Biol Chem 283: 18393-18401.

Noe V, Fingleton B, Jacobs K, Crawford HC, Vermeulen S, Steelant W, Bruyneel E, Matrisian LM, Mareel M. 2001. Release of an invasion promoter E-cadherin fragment by matrilysin and stromelysin-1. J Cell Sci 114: 111-118.

Noskova V, Ahmadi S, Asander E, Casslen B. 2009. Ovarian cancer cells stimulate uPA gene expression in fibroblastic stromal cells via multiple paracrine and autocrine mechanisms. Gynecol Oncol 115: 121-126.

Notohamiprodjo S, Djafarzadeh R, Rieth N, Hofstetter M, Jaeckel C, Nelson PJ. 2012. Cell surface engineering of renal cell carcinoma with glycosylphosphatidylinositol-anchored TIMP-1 blocks TGF- $\beta 1$ activation and reduces regulatory ID gene expression. Biol Chem 393: 1463-1470.

Ohashi K, Naruto M, Nakaki T, Sano E. 2003. Identification of interleukin-8 converting enzyme as cathepsin L. Biochim Biophys Acta 1649: 30-39.

Olson MW, Toth M, Gervasi DC, Sado Y, Ninomiya Y, Fridman R. 1998. High affinity binding of latent matrix metalloproteinase9 to the $\alpha 2(\mathrm{IV})$ chain of collagen IV. J Biol Chem 273: 10672 10681.

Oravecz T, Pall M, Roderiquez G, Gorrell MD, Ditto M, Nguyen NY, Boykins R, Unsworth E, Norcross MA. 1997. Regulation of the receptor specificity and function of the chemokine RANTES (regulated on activation, normal $\mathrm{T}$ cell expressed and secreted) by dipeptidyl peptidase IV (CD26)-mediated cleavage. J Exp Med 186: 1865-1872.

Overall CM, Lopez-Otin C. 2002. Strategies for MMP inhibition in cancer: innovations for the post-trial era. Nat Rev Cancer 2: $657-672$.

Owen KA, Qiu D, Alves J, Schumacher AM, Kilpatrick LM, Li J, Harris JL, Ellis V. 2010. Pericellular activation of hepatocyte growth factor by the transmembrane serine proteases matriptase and hepsin, but not by the membrane-associated protease uPA. Biochem I 426: 219-228.

Palermo C, Joyce JA. 2008. Cysteine cathepsin proteases as pharmacological targets in cancer. Trends Pharmacol Sci 29: 22-28.

Papadimitropoulou A, Mamalaki A. 2013. The glycosylated IgII extracellular domain of EMMPRIN is implicated in the induction of MMP-2. Mol Cell Biochem 379: 107-113.

Parton RG, Simons K. 2007. The multiple faces of caveolae. Nat Rev Mol Cell Biol 8: 185-194.

Patterson BC, Sang QA. 1997. Angiostatin-converting enzyme activities of human matrilysin (MMP-7) and gelatinase B/type IV collagenase (MMP-9). J Biol Chem 272: 28823-28825.

Peinado H, Lavotshkin S, Lyden D. 2011. The secreted factors responsible for pre-metastatic niche formation: old sayings and new thoughts. Semin Cancer Biol 21: 139-146.

Peinado H, Aleckovic M, Lavotshkin S, Matei I, Costa-Silva B, Moreno-Bueno G, Hergueta-Redondo M, Williams C, GarciaSantos G, Ghajar C, et al. 2012. Melanoma exosomes educate bone marrow progenitor cells toward a pro-metastatic phenotype through MET. Nat Med 18: 883-891.

Peng KW, Vile R, Cosset FL, Russell S. 1999. Selective transduction of protease-rich tumors by matrix-metalloproteinase-targeted retroviral vectors. Gene Ther 6: 1552-1557.
Peschon JJ, Slack JL, Reddy P, Stocking KL, Sunnarborg SW, Lee DC, Russell WE, Castner BJ, Johnson RS, Fitzner JN, et al. 1998. An essential role for ectodomain shedding in mammalian development. Science 282: 1281-1284.

Petrella BL, Vincenti MP. 2012. Interleukin-1 $\beta$ mediates metalloproteinase-dependent renal cell carcinoma tumor cell invasion through the activation of CCAAT enhancer binding protein $\beta$. Cancer Med 1: 17-27.

Piperi C, Papavassiliou AG. 2012. Molecular mechanisms regulating matrix metalloproteinases. Curr Top Med Chem 12: 1095-1112.

Powell WC, Fingleton B, Wilson CL, Boothby M, Matrisian LM. 1999. The metalloproteinase matrilysin proteolytically generates active soluble Fas ligand and potentiates epithelial cell apoptosis. Curr Biol 9: 1441-1447.

Prokopchuk O, Liu Y, Henne-Bruns D, Kornmann M. 2005. Interleukin-4 enhances proliferation of human pancreatic cancer cells: evidence for autocrine and paracrine actions. Br J Cancer 92: 921-928.

Proost P, De Meester I, Schols D, Struyf S, Lambeir AM, Wuyts A, Opdenakker G, De Clercq E, Scharpe S, Van Damme J. 1998. Amino-terminal truncation of chemokines by CD26/ dipeptidyl-peptidase IV: conversion of RANTES into a potent inhibitor of monocyte chemotaxis and HIV-1-infection. J Biol Chem 273: 7222-7227.

Puente XS, Sanchez LM, Overall CM, Lopez-Otin C. 2003. Human and mouse proteases: a comparative genomic approach. Nat Rev Genet 4: 544-558.

Qi Y, Duhachek-Muggy S, Li H, Zolkiewska A. 2014. Phenotypic diversity of breast cancer-related mutations in metalloproteinase-disintegrin ADAM12. PLOS ONE 9: e92536.

Quail DF, Joyce JA. 2013. Microenvironmental regulation of tumor progression and metastasis. Nat Med 19: 1423-1437.

Ra HJ, Harju-Baker S, Zhang F, Linhardt RJ, Wilson CL, Parks WC. 2009. Control of promatrilysin (MMP7) activation and substrate-specific activity by sulfated glycosaminoglycans. I Biol Chem 284: 27924-27932.

Rafn B, Nielsen CF, Andersen SH, Szyniarowski P, CorcelleTermeau E, Valo E, Fehrenbacher N, Olsen CJ, Daugaard M, Egebjerg C, et al. 2012. ErbB2-driven breast cancer cell invasion depends on a complex signaling network activating myeloid zinc finger-1-dependent cathepsin B expression. Mol Cell 45: 764-776.

Rakashanda S, Rana F, Rafiq S, Masood A, Amin S. 2012. Role of proteases in cancer: a review. Biotechnol Mol Biol Rev 7: 90101.

Rawlings ND, Waller M, Barrett AJ, Bateman A. 2014. MEROPS: the database of proteolytic enzymes, their substrates and inhibitors. Nucleic Acids Res 42: D503-D509.

Redondo-Munoz J, Ugarte-Berzal E, Garcia-Marco JA, del Cerro MH, Van den Steen PE, Opdenakker G, Terol MJ, GarciaPardo A. 2008. $\alpha 4 \beta 1$ integrin and 190-kDa CD44v constitute a cell surface docking complex for gelatinase B/MMP-9 in chronic leukemic but not in normal B cells. Blood 112: 169-178.

Reis ST, Pontes-Junior J, Antunes AA, Dall'Oglio MF, Dip N, Passerotti CC, Rossini GA, Morais DR, Nesrallah AJ, Piantino C, et al. 2012. miR-21 may acts as an oncomir by targeting RECK, a matrix metalloproteinase regulator, in prostate cancer. BMC Urol 12: 14.

Rosenblum G, Van den Steen PE, Cohen SR, Bitler A, Brand DD, Opdenakker G, Sagi I. 2010. Direct visualization of protease action on collagen triple helical structure. PLOS ONE 5: e11043.

Rothberg JM, Bailey KM, Wojtkowiak JW, Ben-Nun Y, Bogyo M, Weber E, Moin K, Blum G, Mattingly RR, Gillies RJ, et al. 
2013. Acid-mediated tumor proteolysis: contribution of cysteine cathepsins. Neoplasia 15: 1125-1137.

Rozhin J, Sameni M, Ziegler G, Sloane BF. 1994. Pericellular pH affects distribution and secretion of cathepsin $B$ in malignant cells. Cancer Res 54: 6517-6525.

Ruffell B, Affara NI, Cottone L, Junankar S, Johansson M, DeNardo DG, Korets L, Reinheckel T, Sloane BF, Bogyo M, et al. 2013. Cathepsin C is a tissue-specific regulator of squamous carcinogenesis. Genes Dev 27: 2086-2098.

Ruhrberg C, Gerhardt H, Golding M, Watson R, Ioannidou S, Fuijsawa H, Betsholtz C, Shima DT. 2002. Spatially restricted patterning cues provided by heparin-binding VEGF-A control blood vessel branching morphogenesis. Genes Dev 16: 2684 2698.

Ruoslahti E. 1996. RGD and other recognition sequences for integrins. Annu Rev Cell Dev Biol 12: 697-715.

Sameshima T, Nabeshima K, Toole BP, Yokogami K, Okada Y, Goya T, Koono M, Wakisaka S. 2000. Glioma cell extracellular matrix metalloproteinase inducer (EMMPRIN) (CD147) stimulates production of membrane-type matrix metalloproteinases and activated gelatinase $\mathrm{A}$ in co-cultures with brainderived fibroblasts. Cancer Lett 157: 177-184.

Sarrazin S, Lamanna WC, Esko JD. 2011. Heparan sulfate proteoglycans. Cold Spring Harb Perspect Biol 3: a004952.

Schulte M, Reiss K, Lettau M, Maretzky T, Ludwig A, Hartmann D, de Strooper B, Janssen O, Saftig P. 2007. ADAM10 regulates FasL cell surface expression and modulates FasL-induced cytotoxicity and activation-induced cell death. Cell Death Differ 14: 1040 1049.

Seals DF, Courtneidge SA. 2003. The ADAMs family of metalloproteases: multidomain proteins with multiple functions. Genes Dev 17: 7-30.

Seals DF, Azucena EF Jr, Pass I, Tesfay L, Gordon R, Woodrow M, Resau JH, Courtneidge SA. 2005. The adaptor protein Tks5/ Fish is required for podosome formation and function, and for the protease-driven invasion of cancer cells. Cancer Cell 7: 155-165.

Seidah NG, Prat A. 2012. The biology and therapeutic targeting of the proprotein convertases. Nat Rev Drug Discov 11: 367383.

Sevenich L, Bowman RL, Mason SD, Quail DF, Rapaport F, Elie BT, Brogi E, Brastianos PK, Hahn WC, Holsinger LJ, et al. 2014. Analysis of tumour- and stroma-supplied proteolytic networks reveals a brain-metastasis-promoting role for cathepsin S. Nat Cell Biol 16: 876-888.

Sheu BC, Hsu SM, Ho HN, Lien HC, Huang SC, Lin RH. 2001. A novel role of metalloproteinase in cancer-mediated immunosuppression. Cancer Res 61: 237-242.

Shimoda M, Principe S, Jackson HW, Luga V, Fang H, Molyneux SD, Shao YW, Aiken A, Waterhouse PD, Karamboulas C, et al. 2014. Loss of the Timp gene family is sufficient for the acquisition of the CAF-like cell state. Nat Cell Biol 16: 889901.

Shin M, Kadowaki T, Iwata J, Kawakubo T, Yamaguchi N, Takii R, Tsukuba T, Yamamoto K. 2007. Association of cathepsin E with tumor growth arrest through angiogenesis inhibition and enhanced immune responses. Biol Chem 388: 1173-1181.

Sieuwerts AM, Klijn JG, Henzen-Logmand SC, Bouwman I, Van Roozendaal KE, Peters HA, Setyono-Han B, Foekens JA. 1998. Urokinase-type-plasminogen-activator (uPA) production by human breast (myo) fibroblasts in vitro: influence of transforming growth factor- $\beta_{1}$ (TGF $\beta_{1}$ ) compared with factor(s) released by human epithelial-carcinoma cells. Int J Cancer 76: 829-835.

Sjoblom T, Jones S, Wood LD, Parsons DW, Lin J, Barber TD, Mandelker D, Leary RJ, Ptak J, Silliman N, et al. 2006. The consensus coding sequences of human breast and colorectal cancers. Science 314: 268-274.

Sloane BF, Moin K, Sameni M, Tait LR, Rozhin J, Ziegler G. 1994. Membrane association of cathepsin B can be induced by transfection of human breast epithelial cells with c-Ha-ras oncogene. J Cell Sci 107: 373-384.

Strongin AY. 2010. Proteolytic and non-proteolytic roles of membrane type-1 matrix metalloproteinase in malignancy. Biochim Biophys Acta 1803: 133-141.

Stuelten CH, DaCosta Byfield S, Arany PR, Karpova TS, StetlerStevenson WG, Roberts AB. 2005. Breast cancer cells induce stromal fibroblasts to express MMP-9 via secretion of TNF- $\alpha$ and TGF- $\beta$. J Cell Sci 118: 2143-2153.

Sun J, Hemler ME. 2001. Regulation of MMP-1 and MMP-2 production through CD147/extracellular matrix metalloproteinase inducer interactions. Cancer Res 61: 2276-2281.

Sun D, Wang X, Zhang H, Deng L, Zhang Y. 2011. MMP9 mediates MICA shedding in human osteosarcomas. Cell Biol Int 35: 569-574.

Tang L, Han X. 2013. The urokinase plasminogen activator system in breast cancer invasion and metastasis. Biomed Pharmacother 67: 179-182.

Todaro M, Lombardo Y, Francipane MG, Alea MP, Cammareri P, Iovino F, Di Stefano AB, Di Bernardo C, Agrusa A, Condorelli G, et al. 2008. Apoptosis resistance in epithelial tumors is mediated by tumor-cell-derived interleukin-4. Cell Death Differ 15: 762-772.

Turk B. 2006. Targeting proteases: successes, failures and future prospects. Nat Rev Drug Discov 5: 785-799.

Ueki N, Lee S, Sampson NS, Hayman MJ. 2013. Selective cancer targeting with prodrugs activated by histone deacetylases and a tumour-associated protease. Nat Commun 4: 2735.

Valiente $\mathrm{M}$, Obenauf $\mathrm{AC}$, Jin $\mathrm{X}$, Chen $\mathrm{Q}$, Zhang $\mathrm{XH}$, Lee DJ, Chaft JE, Kris MG, Huse JT, Brogi E, et al. 2014. Serpins promote cancer cell survival and vascular co-option in brain metastasis. Cell 156: 1002-1016.

Van Den Steen PE, Wuyts A, Husson SJ, Proost P, Van Damme J, Opdenakker G. 2003. Gelatinase B/MMP-9 and neutrophil collagenase/MMP-8 process the chemokines human GCP-2/ CXCL6, ENA-78/CXCL5 and mouse GCP-2/LIX and modulate their physiological activities. Eur J Biochem 270: 3739-3749.

Vargo-Gogola T, Crawford HC, Fingleton B, Matrisian LM. 2002. Identification of novel matrix metalloproteinase-7 (matrilysin) cleavage sites in murine and human Fas ligand. Arch Biochem Biophys 408: 155-161.

Vasiljeva O, Papazoglou A, Kruger A, Brodoefel H, Korovin M, Deussing J, Augustin N, Nielsen BS, Almholt K, Bogyo M, et al. 2006. Tumor cell-derived and macrophage-derived cathepsin B promotes progression and lung metastasis of mammary cancer. Cancer Res 66: 5242-5250.

Veillard F, Saidi A, Burden RE, Scott CJ, Gillet L, Lecaille F, Lalmanach G. 2011. Cysteine cathepsins S and L modulate anti-angiogenic activities of human endostatin. J Biol Chem 286: $37158-37167$.

Vempati P, Popel AS, Mac Gabhann F. 2011. Formation of VEGF isoform-specific spatial distributions governing angiogenesis: computational analysis. BMC Syst Biol 5: 59.

Wang B, Sun J, Kitamoto S, Yang M, Grubb A, Chapman HA, Kalluri R, Shi GP. 2006. Cathepsin S controls angiogenesis and tumor growth via matrix-derived angiogenic factors. J Biol Chem 281: 6020-6029.

Wang YH, Dong YY, Wang WM, Xie XY, Wang ZM, Chen RX, Chen J, Gao DM, Cui JF, Ren ZG. 2013. Vascular endothelial cells facilitated HCC invasion and metastasis through the Akt and NF-кB pathways induced by paracrine cytokines. J Exp Clin Cancer Res 32: 51. 
Weidle UH, Tiefenthaler G, Georges G. 2014. Proteases as activators for cytotoxic prodrugs in antitumor therapy. Cancer Genomics Proteomics 11: 67-79.

Wolf K, Wu YI, Liu Y, Geiger J, Tam E, Overall C, Stack MS, Friedl P. 2007. Multi-step pericellular proteolysis controls the transition from individual to collective cancer cell invasion. Nat Cell Biol 9: 893-904.

Xu J, Rodriguez D, Petitclerc E, Kim JJ, Hangai M, Moon YS, Davis GE, Brooks PC. 2001. Proteolytic exposure of a cryptic site within collagen type IV is required for angiogenesis and tumor growth in vivo. J Cell Biol 154: 1069-1079.

Yamaguchi H, Takeo Y, Yoshida S, Kouchi Z, Nakamura Y, Fukami K. 2009. Lipid rafts and caveolin-1 are required for invadopodia formation and extracellular matrix degradation by human breast cancer cells. Cancer Res 69: 8594-8602.

Yana I, Sagara H, Takaki S, Takatsu K, Nakamura K, Nakao K, Katsuki M, Taniguchi S, Aoki T, Sato H, et al. 2007. Crosstalk between neovessels and mural cells directs the sitespecific expression of MT1-MMP to endothelial tip cells. J Cell Sci 120: 1607-1614.

Yang X, Wang D, Dong W, Song Z, Dou K. 2010. Inhibition of $\mathrm{Na}^{+} / \mathrm{H}^{+}$exchanger 1 by 5 -(N-ethyl- $\mathrm{N}$-isopropyl) amiloride reduces hypoxia-induced hepatocellular carcinoma invasion and motility. Cancer Lett 295: 198-204.

Yin M, Soikkeli J, Jahkola T, Virolainen S, Saksela O, Holtta E. 2012. TGF- $\beta$ signaling, activated stromal fibroblasts, and cysteine cathepsins $\mathrm{B}$ and $\mathrm{L}$ drive the invasive growth of human melanoma cells. Am I Pathol 181: 2202-2216.

Yong HY, Kim IY, Kim JS, Moon A. 2010. ErbB2-enhanced invasiveness of H-Ras MCF10A breast cells requires MMP13 and uPA upregulation via p38 MAPK signaling. Int J Oncol 36: 501-507.

Yu Q, Stamenkovic I. 1999. Localization of matrix metalloproteinase 9 to the cell surface provides a mechanism for CD44mediated tumor invasion. Genes Dev 13: 35-48.

Yu Q, Stamenkovic I. 2000. Cell surface-localized matrix metalloproteinase-9 proteolytically activates TGF- $\beta$ and promotes tumor invasion and angiogenesis. Genes Dev 14: 163-176. 


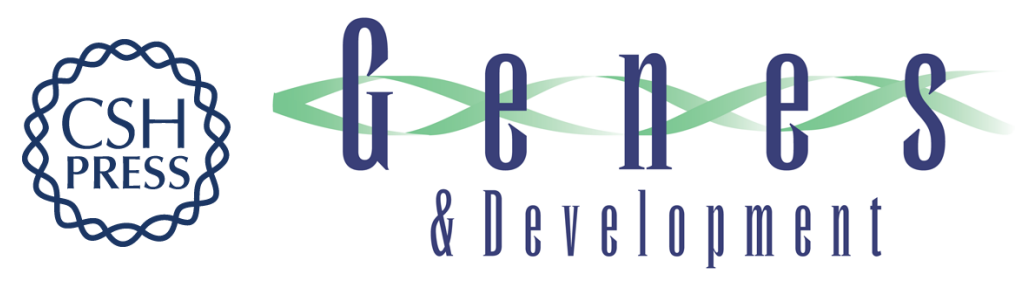

\title{
Pericellular proteolysis in cancer
}

\author{
Lisa Sevenich and Johanna A. Joyce
}

Genes Dev. 2014, 28:

Access the most recent version at doi:10.1101/gad.250647.114

References This article cites 214 articles, 76 of which can be accessed free at: http://genesdev.cshlp.org/content/28/21/2331.full.html\#ref-list-1

Creative This article is distributed exclusively by Cold Spring Harbor Laboratory Press for the first Commons six months after the full-issue publication date (see License http://genesdev.cshlp.org/site/misc/terms.xhtml). After six months, it is available under a Creative Commons License (Attribution-NonCommercial 4.0 International), as described at http://creativecommons.org/licenses/by-nc/4.0/.

Email Alerting Receive free email alerts when new articles cite this article - sign up in the box at the top Service right corner of the article or click here.

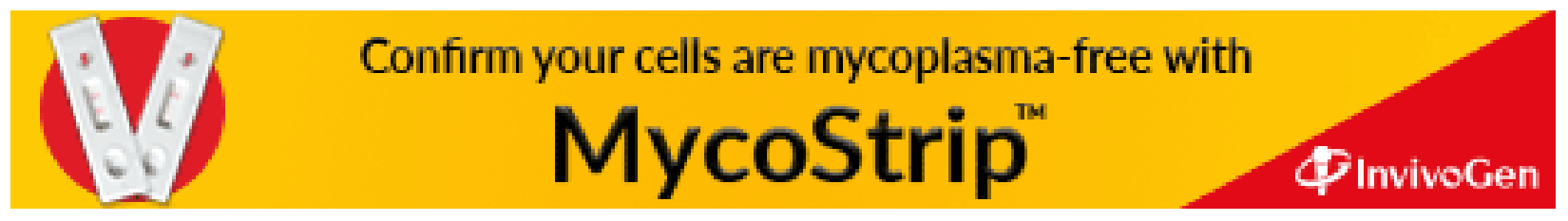

